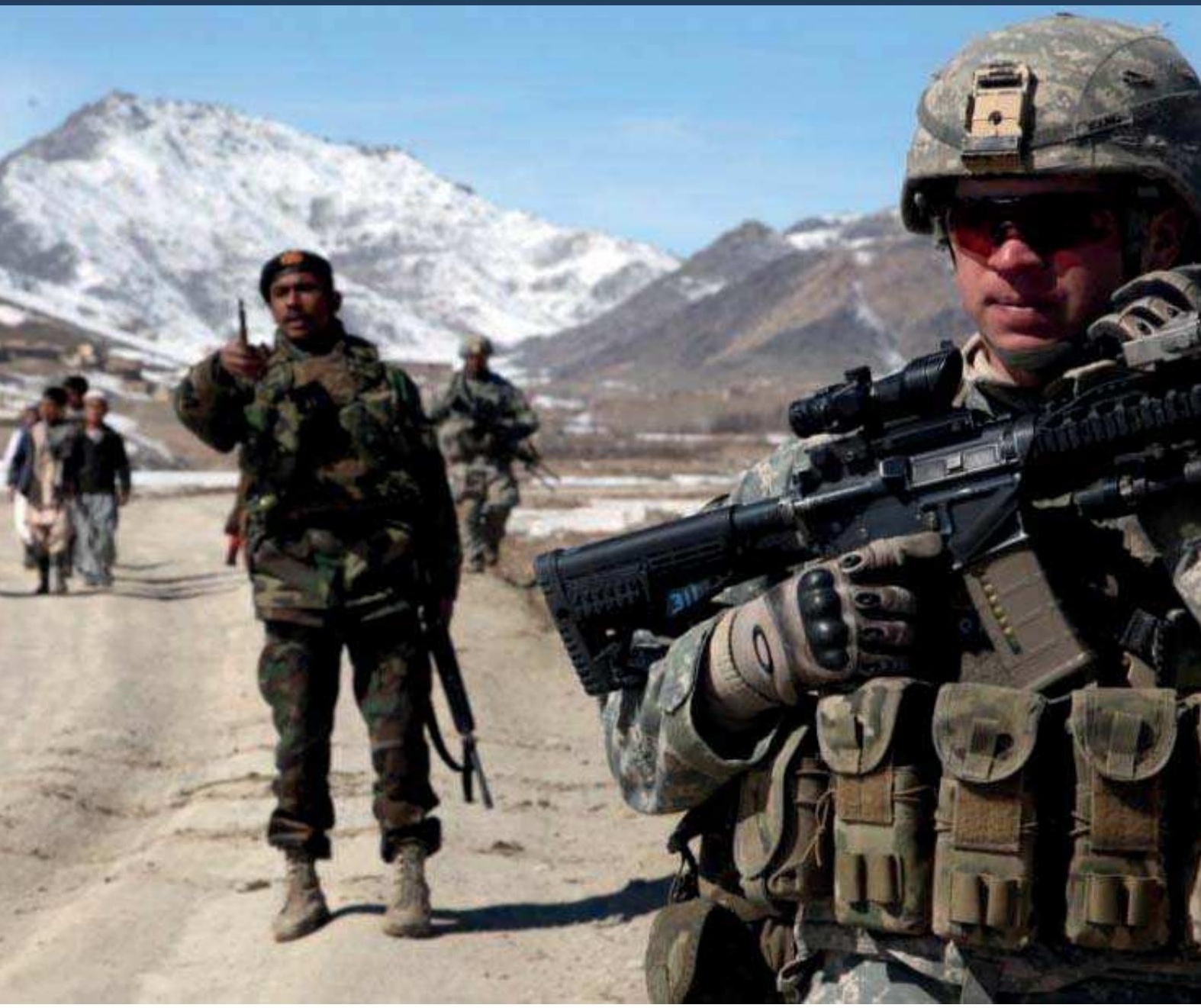

International Intervention and the Use of Force: Military and Police Roles

Cornelius Friesendorf 
SSR PAPER 4

\title{
International Intervention and the Use of Force
}

\author{
Military and Police Roles
}

Cornelius Friesendorf 
Published by

Ubiquity Press Ltd.

6 Osborn Street, Unit 2N

London E1 6TD

www.ubiquitypress.com

Text (C) Cornelius Friesendorf 2012

First published 2012

Transferred to Ubiquity Press 2018

Cover image (C) isafmedia

Editors: Alan Bryden \& Heiner Hänggi

Production: Yury Korobovsky

Copy editor: Cherry Ekins

ISBN (PDF): 978-1-911529-31-6

ISSN (online): 2571-9297

DOI: https://doi.org/10.5334/bbo

This work is licensed under the Creative Commons Attribution 4.0 International License (unless stated otherwise within the content of the work). To view a copy of this license, visit http://creativecommons. org/licenses/by/4.0/ or send a letter to Creative Commons, 444 Castro Street, Suite 900, Mountain View, California, 94041, USA. This license allows for copying any part of the work for personal and commercial use, providing author attribution is clearly stated.

This book was originally published by the Geneva Centre for the Democratic Control of Armed Forces (DCAF), an international foundation whose mission is to assist the international community in pursuing good governance and reform of the security sector. The title transferred to Ubiquity Press when the series moved to an open access platform. The full text of this book was peer reviewed according to the original publisher's policy at the time. The original ISBN for this title was 978-92-9222-202-4.

SSR Papers is a flagship DCAF publication series intended to contribute innovative thinking on important themes and approaches relating to security sector reform (SSR) in the broader context of security sector governance (SSG). Papers provide original and provocative analysis on topics that are directly linked to the challenges of a governance-driven security sector reform agenda. SSR Papers are intended for researchers, policy-makers and practitioners involved in this field.

The views expressed are those of the author(s) alone and do not in any way reflect the views of the institutions referred to or represented within this paper.

Suggested citation:

Friesendorf, C. 2018. International Intervention and the Use of Force: Military and Police Roles. London: Ubiquity Press. DOI: https://doi.org/10.5334/bbo. License: CC-BY 4.0 


\section{Contents}

Introduction

Intervention and Versatile Force

Conceptualising versatile force 10

Understanding the use of force 18

Domestic institutions of intervening states 27

Learning from Experience

Bosnia and Herzegovina 39

Kosovo 48

Afghanistan 58

Conclusions

Key findings 70

Lessons to be learned 73

Critical knowledge gaps 77

Notes 



\section{INTRODUCTION ${ }^{1}$}

The governments of democracies are under pressure from their home populations to intervene in cases of gross human rights violations. A redefinition of sovereignty and the inadequacy of traditional peacekeeping, too, have spurred the use of force. But democracies have to be careful when using force. Proportionality is an obligation under international law and is also enshrined in the constitutions and domestic laws of liberal democracies. Moreover, international organisations mandate many interventions and contribute to their implementation. They are tasked to defend international law and oppose disproportionate force. To this one must add scrutiny by the media and civil society, which document any 'collateral damage'. Last but not least, intervening states, no matter whether as part of post-conflict stabilisation or counterinsurgency, must win the hearts and minds of local citizens. Maximum, indiscriminate force is counterproductive in this regard.

To be both effective and legitimate, the security forces of liberal democracies must cover the entire spectrum of force - maximum, intermediate and minimum - while at the same time calibrating levels of force to the problem at hand. In other words, intervening states must use versatile force.

Practising such versatility is difficult. In liberal democracies, police officers tend to be experts in minimum force and soldiers in maximum force. Versatility challenges such role specialisation, pushing states to militarise their police and policise their militaries. In the extreme, police officers and soldiers are able to switch seamlessly between combat and 
community policing roles. This requires profound changes in the characteristics of security forces, which are difficult to achieve in practice. Such changes also raise political and normative concerns. By militarising the police, intervening states may undermine efforts at community policing and send the wrong message to citizens weary of paramilitary forces. ${ }^{2}$ Policising the militaries holds the risk of degrading war-fighting capabilities. Reconfiguring the roles and responsibilities of security forces may, furthermore, result in battles over funding and competencies and in blurred responsibilities of security forces. Perhaps most importantly, flexible security forces may have to compromise on short-term force protection, which increases the risk of casualties.

Using the right amount of force is a central challenge for democracies intervening in war-torn countries. How do they cope with the task of using force both decisively and cautiously? Why do they often use force differently? And how should they be using force?

This paper explores how liberal democracies have coped with the problem of versatile force in international intervention. The issue is important because a variety of security problems, including political violence, organised crime and riots, feature prominently during and after internal wars. International actors struggle with such problems, which after all defy distinctions that are at the core of the modern democratic state: between internal and external security, crime and war, and police and military work. To this conceptual confusion one must add the fact that in intervention a variety of actors operate alongside one another, including international and domestic, public and private, licit and illicit, overt and covert actors.

The result is improvisation and idiosyncrasy. But no matter how improvised and idiosyncratic, the use of force by international intervention forces alters security conditions in war-torn countries and sends symbolic messages. Despite the importance of the use of force in international intervention, too little is known about this topic. Thus this paper has three objectives: empirical, explanatory and practical ones.

Empirically, the paper analyses the use of force by four liberal democracies: the United States (US), the United Kingdom (UK), Germany, and Italy. It focuses on three international interventions: in Bosnia and Herzegovina, Kosovo and Afghanistan. The analysis shows that the selected states have often dealt differently with political violence (terrorism and 
insurgency), organised crime and riots. The US has tended to rely on maximum force, the German military on show of force and the German police on minimum force. By contrast, the UK (especially the British Army) and Italy (especially its gendarmerie force, the Carabinieri) have been more ready to embrace versatile force.

The paper offers a tentative explanation of such policy difference. As shown in section 2, the literature on the use of force has shortcomings, so the paper offers an explanatory model. Legal, practical and normative concerns promote the use of versatile force, as mentioned above. However, these factors do not determine intervention practices. To understand differences in the use of force, one must focus on the domestic institutions of intervening states, i.e. the formal and informal rules governing the use of force. These institutions mediate between sources of pressure to use versatile force and policy outcomes. All liberal democracies face similar pressure. Yet, because of differences in their domestic institutions, they use force differently.

The third objective of this paper is to discuss practical implications of versatile force. Different levels of force have pros and cons. A focus on minimum force may render security personnel soft targets; a posture emphasising maximum force may lead security forces to over- or underreact. Versatility potentially enhances effectiveness. But the blurring of police and military roles carries costs, too. The trick is to square policemilitary convergence with police-military specialisation.

The case studies examined in this paper were selected non-randomly. Bosnia and Herzegovina, Kosovo and Afghanistan have been major interventions in terms of money spent, personnel deployed and casualties incurred. The experiences from these three interventions have had a profound impact on the security practices and discourses of all liberal democracies. The three sites were also selected because in all cases international actors were given executive mandates, and because the interventions have taken place in different regions and over a sufficiently long period of time (the period of analysis is 1996-2011). However, while the United Nations (UN) provided the mandate for all three operations and also deployed police missions to Bosnia and Herzegovina and Kosovo, NATO (North Atlantic Treaty Organization) and the European Union (EU) deployed military and police missions. Furthermore, the opposition encountered by international actors varied. While the interventions in Bosnia and 
Herzegovina after the Dayton Agreement and Kosovo after the Kumanovo Agreement can be classified as post-conflict interventions, external actors have been fighting a war in Afghanistan since late 2001. Such differences make it possible to go beyond the idiosyncrasies of individual cases and glean a broader picture.

The US, UK, Germany and Italy have been selected because of their prominent roles in Bosnia and Herzegovina, Kosovo and Afghanistan. Also, all four states are Western liberal democracies. Membership in NATO and the EU (the US is a member of NATO only) has led to a convergence of security policies and capabilities. Yet despite these similarities, the use of force often differs. To be sure, similarities are more pronounced with regard to the military than the police, where size, centralisation, militarisation and the role of criminal justice agencies differ. ${ }^{3}$ To gauge the causal role of domestic institutions, states with differing policing structures have been chosen.

The empirical illustrations (section 3) draws on the method of structured, focused comparison. The analysis is focused because it is limited to the use of force, and it is structured because the same questions are asked in each case study: how do sending countries' institutions influence the use of force; and which international actor emphasises which level of force? The aim is to describe the use of force by international actors in wartorn countries and shed light, in a tentative manner, on the underlying causes.

The paper draws on secondary literature, official documents and reports from the news media. In addition, interviews were conducted with representatives of governments, international organisations, security forces, academia, the media and non-governmental organisations (NGOs). These were held in the Balkans (Bosnia and Herzegovina, Kosovo and Serbia) between 2005 and 2008, and during four field missions to Afghanistan between 2009 and 2011. The format of informal interviews was preferred, as it allowed interlocutors to speak openly; the downside was that most interlocutors wished to remain anonymous. Care was taken to avoid the presentation of marginal views.

This paper reserves the term 'force' to statutory security forces and the term 'violence' to non-state actors. This is not to deny that security forces can misuse force, and that violence used by 'deviants' may be regarded as legitimate. A riot, for instance, may be seen as the only option 
for marginalised groups to voice their dissent against the established order. $^{4}$

Two caveats require mentioning. First, this paper does not purport to be comprehensive. A comprehensive account would need to explain the origins of domestic institutions. For example, David Bayley reveals the complex political, economic and social dynamics behind the evolution of police forces. ${ }^{5}$ This paper merely sketches out the most important recent historical experiences and how they have shaped the use of force. Any attempt at comprehensiveness would face significant methodological challenges as well. A lack of data and difficulty of access to sites of intervention create gaps in the chronological and causal account. Data are particularly poor on special military and police forces and intelligence agencies - often it is unclear who is doing what, where, how and why.

A second caveat pertains to policy effectiveness. Even in stable countries and even when looking at the police only, measuring the effectiveness of law enforcement is tricky, for reasons of secrecy and methodology. How many terrorist acts have not been committed because of successful intervention? Moreover, law enforcement is not the only factor shaping crime; and there are no standards for measuring effectiveness. The lack of data and problems of access in war-torn countries exacerbate these difficulties. Nevertheless, the empirical cases do refer to successes and failures of intervention, using yardsticks such as the protection of vulnerable citizens against violence.

Section 2 conceptualises the use of force in international intervention. Section 3 discusses the use of force in Bosnia and Herzegovina, Kosovo and Afghanistan. Section 4 takes a practical turn, analysing the empirical results and discussing options for future intervention. 


\section{INTERVENTION AND VERSATILE FORCE}

This section first conceptualises versatile force. In a second step it shows that states have much leeway in how they use force in war-torn countries, and proposes a model that helps to understand how states cope with the problem of versatility. It concludes by sketching out the domestic institutions of the US, UK, Germany and Italy governing the use of force.

\section{Conceptualising versatile force}

Much has been written about how and why states use force, but gaps remain. These gaps result not least from disciplinary fault-lines. For instance, students of police studies and of criminology have little to say about the military. ${ }^{6}$ Students of international law have paid much attention to the use of force, but their focus on legal norms leads them to neglect the political factors driving the use of force, as well as policy implementation.

Students of security studies during the Cold War focused on maximum (conventional and nuclear) military force. ${ }^{7}$ This perspective helps to understand how states avoid, wage or win war against opponent armies, but says little about problems for which maximum force is an ill fit. Debates on minimum force took place, but on the margins of security studies. ${ }^{8}$

After the Cold War, security risks such as organised crime, nuclear proliferation and terrorism moved to centre stage in national and international security. As security practices changed, scholarly outlooks broadened. Much attention has since been paid to the internationalisation 
and militarisation of the police. ${ }^{9}$ Authors have also focused on the policisation of the military, ${ }^{10}$ with niche debates examining issues such as the use of non-lethal weapons by the military. The growing interest in the reconfiguration of force is reflected in studies on security actors such as gendarmeries, ${ }^{11}$ paramilitary police, ${ }^{12}$ special forces ${ }^{13}$ and intelligence agencies. ${ }^{14}$ Most works analyse how the blurring of police and military tasks has played out in the US, ${ }^{15}$ with fewer studies on blurring elsewhere. ${ }^{16}$ One study looks at the police-military interface from a conceptual and comparative perspective. ${ }^{17}$

The use of force in international intervention has been of much interest, too. Numerous works examine the pros and cons of humanitarian intervention and the evolving norm of the 'Responsibility to Protect' (R2P). However, this type of scholarship predominantly shows whether and why states militarily intervene in crisis zones, not how they use versatile force. Students of strategic studies do discuss the problem of calibrating force in a new security environment. ${ }^{18}$ But few works take a comparative approach, revealing different national caveats, military doctrines and threat perceptions. ${ }^{19}$ In other words, analyses tend to gloss over the nuances of international intervention.

There are also gaps in explanations of the use of force. Authors have captured the changing nature of conflict through terms such as 'new wars', 'global insurgency' and 'war amongst the people', ${ }^{20}$ and called for 'cosmopolitan law enforcement' and 'policing wars'. ${ }^{21}$ Such terms capture the blurring roles of security forces, and implicitly call on international actors to respect norms such as proportionality and necessity when intervening in failing states. But in and of themselves, the terms are of little explanatory value.

Critical security studies scholars argue that security forces try to survive as institutions and therefore construct security problems in a way that suits their interests. ${ }^{22}$ But this claim may be exaggerated. Institutions are resilient to change. The military is a 'reluctant recruit' when it comes to contributing to law enforcement. ${ }^{23}$ As military sociologists have shown, the military is worried about the effect of peacekeeping on military identity and combat readiness, even though it may see opportunities in peacekeeping, such as training benefits. ${ }^{24}$

An alternative explanation of changing patterns of force would stress that security forces act rationally, in a way best suited for solving a problem 
and a way that is expected of them. As shown below, liberal democracies are under pressure to use versatile force. Yet states often act differently.

A popular paradigm describing intervention in war-torn countries is the security gap, which was coined in 1998 by a group of scholars and practitioners. ${ }^{25} \mathrm{~A}$ security gap results from a deployment gap (international actors fail to deploy civilian police forces in time) and an enforcement gap (domestic security forces are unable to enforce the law, and international military forces eschew this role). Authors have empirically examined security gaps, contributing to a better understanding of international intervention. ${ }^{26}$ Yet the paradigm cannot properly account for differences in the use of force. Also, it suggests that security gaps occur during the early phase of intervention, and then go away - but this is an overly linear, deterministic image of a more complex process. Furthermore, the literature on security gaps does not discuss actors such as special forces.

The main cause of these limits is lack of comparative research. Most of those who have developed the paradigm are former US security practitioners and decision-makers who are concerned about the difficulties faced by the US in operating in police-military grey zones. They refer to US conditions that, in the past, have led security gaps to open up, such as missing gendarmerie forces and the inability of the US federal government to deputise US local police forces. To be sure, there are also works that examine other countries' difficulties in policing war-torn countries. But such works tend to be wedded to the idiosyncrasies of the particular case, instead of offering comparative analyses. ${ }^{27}$

This paper contributes to filling these gaps, by developing a model for understanding the use of force across countries, comparing its use by several intervening states and examining a range of security forces. But what is versatile force? Versatility refers to the ability of security forces to calibrate levels of force. A distinction can be drawn between three levels of force: maximum, intermediate and minimum. International intervention requires all three levels, given the large spectrum of security problems encountered and the limitations of each of the three levels of force alone. Security forces are versatile when they are able to adapt their material, educational, cultural, legal, organisational and operational characteristics, and thus levels of force, to their environment (these six characteristics are discussed further below). ${ }^{28}$ 
Figure 1: The continuum of force and corresponding security forces

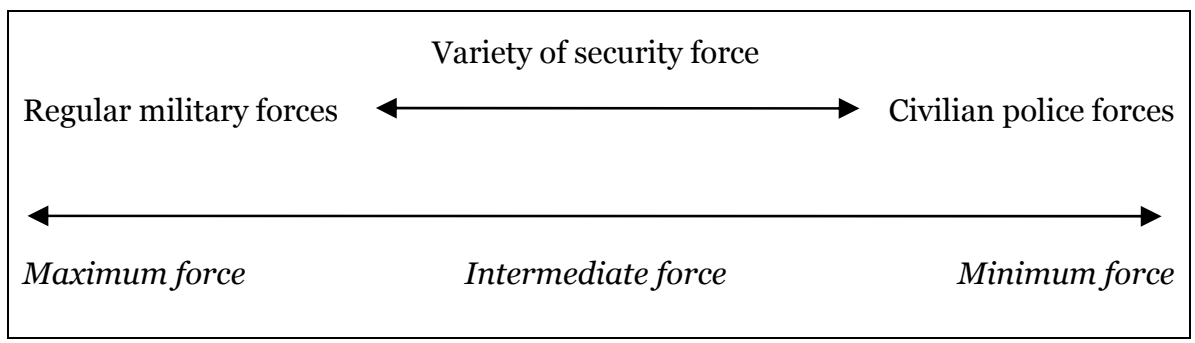

In liberal democracies, different security forces typically specialise in different levels of force. Figure 1 illustrates the relationship between levels of force and the position of security forces along this continuum.

Regular military forces specialise in maximum force; when they are versatile, these forces may move towards the minimum force end of the continuum. Civilian police forces specialise in minimum force, and may be regular uniformed police or plainclothes detectives working for criminal investigation departments (CIDs). When versatile, they are able to move towards maximum force.

A variety of security actors are able to operate on various points along the continuum, scaling up or down the use of force. Such actors include special military forces, military police, gendarmeries, special police forces such as special weapons and tactics (SWAT) teams, formed police units (FPUs) and paramilitary units of intelligence agencies.

States intervening in war-torn countries are under pressure to use versatile force for several reasons. Sources of pressure can be found on the international level, at the domestic level of intervening states and in wartorn countries.

Changes in the security environment are one important reason. After the Cold War, for the West communism was no longer the main threat. Instead, in the 1990s governments saw transnational organised crime as a top priority. ${ }^{29}$ After the attacks of 9/11, terrorism moved to the top of the international security agenda. The wars in Iraq and Afghanistan then merged counterterrorism with counterinsurgency.

Terrorism, insurgency and organised crime are different phenomena, requiring different counter-strategies. When looking at motives, for example, members of organised crime groups want to make money, not topple governments. But there is overlap, too. Some criminal groups resort 
to terrorist tactics, and some terrorist and insurgent groups receive funding from illicit sources. ${ }^{30}$ Contemporary security risks such as terrorism, insurgency and organised crime share other features: they cover the entire spectrum of violence, and their protagonists tend to employ violence asymmetrically, to offset the superior capabilities of states.

Efforts to cope with security risks have spurred versatile force. Indiscriminate maximum force is largely useless against hybrid networks with in-built redundancies. As part of military transformation, states that can afford it, especially the US, rely on technology and special military forces. ${ }^{31}$ On the police side, many countries have been militarising their police, as indicated by the rise of gendarmerie forces. ${ }^{32}$ As distinctions between crime and war, and internal and external security, collapsed, so did distinctions between police and military tasks within liberal democracies (although this process has played out unevenly across states).

Upholding police-military divisions of labour is particularly difficult in war-torn countries, with regard to both international and local security forces. The end of the Cold War saw an increase in internal wars, often accompanied by the collapse of state institutions, as was the case in Yugoslavia. So-called new wars feature state, para-state and non-state armed actors. ${ }^{33}$ Instead of fighting militarily organised enemies, armed groups often attack civilians. Actors using violence may be driven by political, economic, ethnic and religious motives.

Particularly against insurgents and terrorists relying on asymmetric tactics, calibrating the use of force is tricky. A minimum force approach implies caution and the arrest of opponents. The aim is to gain the trust and support of the population. ${ }^{34}$ The downside is an increase in risk for security personnel, at least in the short run. An alternative approach is maximum force. ${ }^{35}$ This approach may enhance force protection in the short term; but due to the factors discussed below, liberal democracies cannot exclusively rely on maximum force.

International actors intervening in war-torn countries also face organised crime groups. Such groups are not necessarily opposed to an international presence: they may appreciate the relative stability peacekeepers bring, as all-out war is bad for most business, and they benefit from international demand for licit and illicit services and goods. ${ }^{36}$ Yet organised crime in war-torn countries is related to violence. This is particularly the case with kidnapping, extortion and the smuggling and 
trafficking of people and goods (such as drugs, weapons, cigarettes, oil, timber and precious stones). Criminals may threaten and use violence against partners in crime or their victims. When cornered, they may also attack members of international or domestic security forces. In war-torn countries the threshold for killing a member of the security forces is often lower than in stable countries, due to war-time brutalisation and the low risk of successful prosecution given dysfunctional law enforcement and justice systems. Operations against organised crime in war-torn countries are therefore high risk, and require versatile force capabilities such as those possessed by SWAT teams.

Riots (including violent demonstrations and looting) also blur divisions of labour between the police and the military. In stable countries crowd and riot control (CRC) tends to be the purview of specialised police forces. Only in rare cases do confrontations between demonstrators and security forces become deadly. It is different in war-torn countries, where rioters may attack vulnerable citizens and officials, in some cases using lethal means. Regular troops, unless trained and equipped for such scenarios, have a choice between shouting or shooting to disperse violent crowds.

Thus war-torn countries feature a variety of security problems that invite versatile force. Another factor plays a role: a redefinition of sovereignty. During the Cold War, security practices and discourses revolved around state security. Western powers, particularly the US, frequently intervened in weaker states in the so-called third world to bolster friendly regimes. Shoring up the security of the state in many cases was detrimental to the security of individuals, as human rights violations by pro-Western authoritarian governments in Latin America and elsewhere demonstrate. ${ }^{37}$

After the Cold War, societies and individuals became more important as referent objects of security, and international intervention became a feasible option in cases of crimes against humanity. New concepts such as human security, humanitarian intervention and R2P, as well as institutions such as the International Criminal Court, have driven, and been the result of, a reconceptualisation of sovereignty. This reconceptualisation puts the governments of liberal democracies (which are primary drivers behind this trend) under pressure to intervene whenever human rights are systematically violated. NGOs, journalists and public intellectuals are quick 
in pointing the finger at governments unwilling to intervene. The term 'CNN effect' encapsulates the impact of public opinion on the foreign policies of liberal democracies.

Concomitant with these changes, there has been a shift from traditional peacekeeping to complex peace operations. ${ }^{38}$ Traditional peacekeeping was based on the consent of conflict parties, neutrality and minimum force. After the Cold War, intervention in internal wars challenged these principles. Peace operations were no longer limited to classical tasks such as observing ceasefires; they now included a variety of tasks, ranging from organising elections to security sector reform (SSR) and SSR-related tasks such as the disarmament, demobilisation and reintegration (DDR) of former combatants. In many peace operations international actors were given executive mandates, particular when acting under Chapter VII of the UN Charter. In some cases, such as in Afghanistan, international actors engaged in war-fighting.

Thus three factors - a new security environment, a redefinition of sovereignty and a redefinition of peacekeeping - have put pressure on states to use force. But using force is not good enough: liberal democracies are under pressure to calibrate levels of force to the problem at hand. Three factors call for versatility: international law, the presence of international organisations and the need to win the hearts and minds of citizens in war-torn countries.

International law imposes significant constraints on the use of force. The UN forbids the use of force abroad, except in self-defence and to avert threats to international peace and security under a UN Security Council mandate. Also, in using force, states must abide by rules. International humanitarian law (IHL) obliges states participating in hostilities to respect the principle of proportionality. This principle is closely related to principles of military necessity and the distinction between combatants and noncombatants. The proportionality principle stipulates that attacks are prohibited that 'may be expected to cause incidental loss of civilian life, injury to civilians, damage to civilian objects, or a combination thereof, which would be excessive in relation to the concrete and direct military advantage anticipated ${ }^{39}$ IHL has broadened its traditional focus on interstate war (international armed conflict), and now regulates internal wars (non-international armed conflict), too. In addition to, and complementary 
with, IHL, international human rights law (IHRL) imposes obligations on individuals participating in armed conflicts.

International efforts to regulate the use of force have traditionally focused on the military. But international law applies to armed actors no matter their status, thus imposing obligations on police as well. Some rules specifically address police forces. The principle of proportionality features prominently in guidance for police put forward by international organisations such as the UN, the Organization for Security and Cooperation in Europe and the Council of Europe. ${ }^{40}$

The principle of proportionality is enshrined in the constitutions, laws and security doctrines of many states, particularly liberal democracies. In fact, liberal democracies have been important promoters of international law - international and national rules governing the use of force have complemented and reinforced one another.

If, as mentioned above, democracies are under public pressure to stop gross human rights violations, civil society equally calls for caution when using force. Cases of 'collateral damage' are quickly made public to a global audience, putting pressure on political, military and police decisionmakers alike. Particularly the governments of liberal democracies are weary of public criticism of exaggerated force. ${ }^{41}$ After all, democratic governments depend on public support. Security forces thus have to act decisively and cautiously at the same time, shifting between different levels of force.

Another factor conducive to versatile force is the presence of international organisations. These provide the mandate for many international interventions and contribute to mission implementation, by placing military and police forces under a theatre commander. The representatives of international organisations are tasked to defend international law, which reduces the risk of states using force inappropriately. The UN has issued troop-contributing states with recommendations for the development of rules of engagement that incorporate proportionality and necessity. ${ }^{42}$

As part of their efforts to regulate the use of force, international organisations envisage specific police and military roles: peacekeeping doctrines prescribe a linear progression whereby international military forces are the main actors at the early stage of a peace operation, and then hand over competencies to international and local police forces. ${ }^{43}$ The UN is not the only organisation trying to establish viable relations between the 
various contributors to peace operations. NATO members have harmonised their military doctrines, including in 'grey' peace operations between traditional peacekeeping and peace enforcement. ${ }^{44}$ An important element in this has been the concept of civil-military cooperation. It has increased military awareness of civilian needs and norms, leading the military to be more cautious when applying force.

The last, but not least important, factor pushing states to calibrate use of force to the problem at hand is functional: intervening states must win the hearts and minds of local citizens. Maximum, indiscriminate force would be ineffective and counterproductive. Relying on massive firepower when the risk of civilian casualties is high may violate international and national law and cause local grievances. Moreover, arresting insurgents or terrorists holds practical advantages over killing them because they may provide vital information. Arrest operations require versatile force options, and imply greater risks than frontal assaults using massive firepower.

\section{Understanding the use of force}

The above-mentioned factors put pressure on states to use versatile force in war-torn countries. However, these factors do not determine policy options: states retain significant autonomy in the use of force.

Scholars analysing the power of norms tend to focus on specific norms. It is clear what states must do to comply with norms against excluding women from voting, racial discrimination or the use of landmines. ${ }^{45}$ With regard to the use of force, appropriate action has been roughly demarcated. Standing by in the face of crimes against humanity and using indiscriminate maximum force would both be inappropriate. But such guidance is very broad. The norm of versatile force, if a norm at all, allows for several courses of action.

If the public (of both sending and host states) is quick to criticise governments for not using enough force, it also criticises the use of disproportionate force. But many local citizens may support maximum force against those regarded as spoilers of peace. Maximum force, to the degree that it does not harm innocent bystanders, may be regarded as just punishment or having a deterrent effect on spoilers. Moreover, the redefinition of sovereignty and the shift towards peace enforcement do not enjoy universal support. The use of force may be regarded as distracting 
from conflict prevention, and as attempts by powerful Western states to spread features of the 'liberal peace' such as parliamentary democracy and capitalism across the world in the guise of militarised humanitarianism. ${ }^{46}$

International law does not offer any blueprints, either. In contemporary conflict it is difficult to distinguish between combatants and non-combatants, war and peace, international and non-international armed conflict, and military and law enforcement objectives. At what point should peacekeepers intervene to protect civilians, and what are 'normal' levels of violence in conflict zones? ${ }^{47}$ How many members of Osama Bin Laden's family and entourage could justifiably be killed by a missile strike that would eliminate the leader of Al Qaeda? ${ }^{48}$ If an international mandate allows military forces to establish a 'safe and secure environment', does the containment of violent demonstrations become a military objective, and which levels of force are permissible to stop a mob when innocent bystanders are present?

To counter violence, states may adopt different paradigms, such as a warfare or law enforcement paradigm. The administration of George W. Bush, by declaring a 'war on terror', avoided constraints that a law enforcement framework based on IHRL would have imposed. ${ }^{49}$ By contrast, the British chose a law enforcement framework in Northern Ireland: ${ }^{50}$ regular courts charged soldiers as well as Irish Republican Army (IRA) terrorists with crimes that included manslaughter and murder.

Various aspects of security policy are the subject of heated debates, which indicates that international law provides only limited guidance. The extraterritorial use of force against non-state actors raises controversy, ${ }^{51}$ as does targeted killing, ${ }^{52}$ the definition of terrorism ${ }^{53}$ and the internment of prisoners in non-international armed conflict. ${ }^{54}$ Efforts are under way to go beyond the jus ad bellum and the jus in bello, and define actors' rights and obligations as part of a jus post bellum. ${ }^{55}$ The principle of proportional force is open to interpretation, too. ${ }^{56}$ If international law gives much leeway to intervening states nowadays, this was even more the case before and during the peace operations of the 1990s, which spurred efforts to clarify obligations under international law.

Problems of compliance exacerbate legal uncertainty. Powerful states can ignore IHL and IHRL, or apply international law selectively, depending on political gratuity (doing so is particularly easy when states have not signed up to international agreements). The detention facility of 
Guantanamo, the practice of rendition and methods that amount to torture, and the treatment of 'unlawful combatants' by the administration of George W. Bush are notorious examples. These practices were enabled by, among others things, the fact that the US, in contrast to European states, disagreed that IHRL applies to armed conflict.

Compliance is not least a problem because of weak sanctioning. In peace operations, international actors are generally given immunity from domestic prosecution, and sending states are reluctant to prosecute and punish members of their security forces for any wrongdoing. The effectiveness of legal standards thus significantly depends on the political will of troop-contributing countries.

Complications also stem from the fact that it is often unclear which laws apply. In Kosovo, in the face of a confusing mix of international law, national laws of sending states, UN regulations and domestic law, NATO units tended to implement their respective national laws. ${ }^{57}$ Different legal outlooks exacerbate these complications. For the police, civil and criminal law and, in extension, IHRL provide the frame, whereas the military is told to respect IHL. The police and the military may therefore not be on the same page when planning and conducting operations. ${ }^{58}$

International organisations allow for various levels of force, too. Officially, police and military officers operate under the banner of international organisations. But in practice, states retain much control over 'their' police and military forces. The vagueness of mandates indicates the unwillingness of states to cede control over vital areas of security. For example, tasking the military to establish a 'safe and secure environment' may be interpreted as including or not including operations against organised crime. Differences in domestic institutions lead troopcontributing states to impose caveats on the use of 'their' troops. ${ }^{59}$ These caveats hamper the achievement of mission objectives as defined by international organisations. ${ }^{60}$ Commanders of multinational forces become managers: their role is political, and they spend much time trying to convince troop-contributing countries to lift national caveats. Civilian leaders who have to hold coalitions together, such as special representatives of the UN Secretary-General, face similar challenges.

Hence the need to win hearts and minds, public pressure, changing views on sovereignty, demands for SSR, norms of international law and the presence of international organisations affect all states intervening in war- 
Figure 2: Understanding the use of force in international intervention

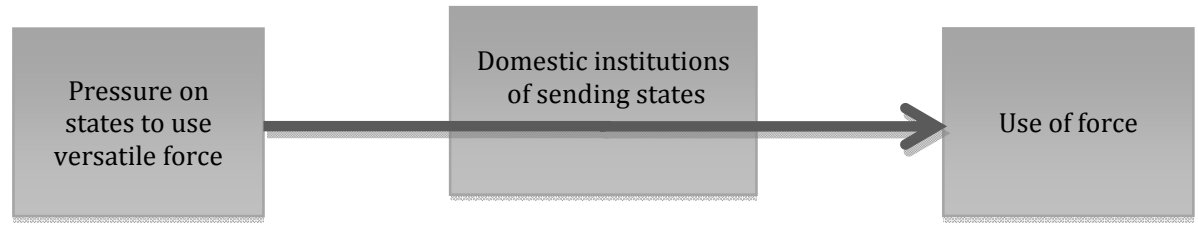

torn countries, and in particular democracies. Yet these factors do not determine the way intervening states use force; they constrain policy options, but only so much. To paraphrase Carl Schmitt, actors are sovereign that draw distinctions between internal and external security, crime and war, and police and military work, and that define security priorities, security paradigms and levels of force.

What, then, explains differences in levels of force? This paper argues that domestic institutions of intervening states mediate between pressure to use versatile force, on the one hand, and intervention practices on the other. As domestic institutions vary, so do intervention practices. Figure 2 illustrates the causal argument.

Institutions are formal and informal rules that govern human behaviour. ${ }^{61}$ For the purpose of this paper, institutions are defined as formal and informal rules that govern the use of force. Formal rules comprise constitutions, laws, regulations, doctrines and rules of engagement. Informal rules are norms that enable or constrain the use of force, and result from positive or negative experiences with the use of force in the past. Studies on norms, as well as on strategic, political and organisational culture, reveal how ideational factors influence policy. ${ }^{62}$

Institutions can and do evolve. This may happen incrementally or due to shocks such as the Second World War or 9/11. However, institutions are resilient to change; they set countries on paths from which they cannot easily deviate. ${ }^{63}$ Such path dependency helps to explain the relative continuity in the way states use force in war-torn countries.

Before discussing differences in intervening states' domestic institutions, similarities must be noted. Most importantly, all liberal democracies have difficulties using versatile force because their security forces specialise in specific levels of force. As the following paragraphs demonstrate, specialisation is manifested in material, educational, cultural, 
legal, organisational and operational characteristics of police and military forces. ${ }^{64}$

First, soldiers and police officers use different equipment and technology (material characteristics). The military can inflict more damage on opponents than the police because it uses more powerful weapons, and may have satellites and other systems vital for directing firepower in modern warfare. The police may also use lethal force, but their weaponry imposes limits.

Second, education matters (educational characteristics). Combat is at the centre of military training, and so is thinking in terms of friend and foe. The police are prepared for the use of force, too, but only exceptionally and as a last resort. They are trained to use persuasion first, and treat offenders as citizens and not as enemies. Because of this, and because police officers generally operate in more permissive environments, they are less likely to use lethal force than soldiers.

Third, soldiers' cultural attributes differ from those of police officers with regard to language, appearance, place of living (in barracks or among the community) and beliefs (cultural characteristics). These cultural straits forge weaker links between soldiers and communities than is the case with police officers. Being in tune with the community is crucial for the police, as crime prevention and investigation hinge on public support. It also helps to prevent situations from reaching the point where the use of force becomes necessary.

Fourth, military and police forces have different legal status and are controlled by different ministries (legal characteristics). Furthermore, military activities are usually governed by $\mathrm{IHL}$ as well as by military laws and statutes. This legal framework allows for the use of maximum force to reach military objectives. The police, in contrast, operate under civil, criminal and police law. This framework calls for highly discriminate force, and usually only after an act of crime has been committed.

Fifth, organisational structures vary (organisational characteristics). Military units, on average, are large and have command structures marked by strict hierarchy and secrecy. Police officers operate in smaller units. Hierarchy and secrecy matter, but police officers tend to have more discretion in their work; they must use their common sense and make decisions without always asking for direction from superiors. 
Sixth, tasks differ. The military is geared towards combat, whereas police officers are tasked to prevent and investigate crime, and to reply to service requests from the public (operational characteristics). Doctrines such as 'community policing' generally regard minimum force as a precondition for successful crime prevention and public service.

Achieving versatility demands changes in the six characteristics outlined above. For regular military units such as combat infantry to be versatile, soldiers would have to avoid relying on lethal weapons as a default position, talk first, appear less martial, consider legal obligations beyond the laws of war, operate in smaller units and work closely with the public. For regular police officers to move towards versatility, they would have to be comfortable with weapons such as automatic rifles, be prepared for the use of lethal force, demonstrate a martial attitude, understand military laws and regulations, operate in larger units and switch from crimefighting to combat if necessary.

In contrast to regular soldiers and civilian police officers, other security forces find it easier to use versatile force, as versatility is built into their characteristics. Non-regular military and police forces have hybrid features that allow them to scale up or down the use of force. For instance, special military forces are able to use maximum force, but also scale down force if necessary, as their training tells them to weigh tactical gains against strategic costs. Mediterranean gendarmeries include units specialising in tasks such as CRC and counterterrorism; yet all gendarmes are supposed to be versatile.

Specialisation finds its strongest expression in restrictions on the domestic use of the military. Understanding these restrictions is important for understanding the use of force in international intervention. After all, in war-torn countries the military is often tasked to perform what one may regard as internal security tasks. Experiences of performing such tasks at home - or the lack thereof - shapes military preparedness to perform them abroad. Domestic military deployments were particularly restricted, when looked at over time and space, during the Cold War and in the Euro-Atlantic area. Two conditions account for this.

The first pertains to security problems. Governments are likely to employ the military domestically when public unrest and criminalised activities threaten the stability of the state. ${ }^{65}$ The 1648 Treaty of Westphalia marks the beginning of the modern state system. Yet the consolidation of 
states took a long time, and only gradually did governments succeed in establishing a monopoly over the use of force. In their fight against brigands, revolutionaries and rioters at home, governments frequently drew on military or militia forces. ${ }^{66}$ The historic role of the military is thus both an internal and an external one.

By contrast, a dichotomy of external threats versus internal crime problems tends to keep the military out of the internal security realm. As modern European states consolidated themselves, a distinction between an external military sphere and an internal police sphere emerged. ${ }^{67}$ The creation of mass armies and ever more destructive weapons increased the stakes; total war called for highly specialised armed forces. ${ }^{68}$ The First World War pitched large industrialised armies against one another; the same was the case during the Second World War. Here things were more complicated, however. In empires such as the Third Reich, drawing a line between inside and outside is difficult. Attempts by Hitler's conglomerate of Wehrmacht, SS and Gestapo units to destroy political opponents and partisans integrated police and military elements. Police-military convergence occurred elsewhere, too. In India the British Empire used soldiers and paramilitary forces for policing not only the frontier zones but also cities. ${ }^{69}$ To eliminate Native American opposition to US state-building, the government in Washington regarded its military as a quasi-police force.

During the Cold War, and in the Euro-Atlantic area, things were simpler. The boundaries between NATO and the Warsaw Pact were clearly demarcated, and the threat of nuclear Armageddon created a need for highly specialised armed forces prepared for using maximum force. Internally, less was to be feared. Countries feared communist uprisings in the 1940s and 1950s, the riots of the 1960s and the terrorism of the 1970s. But only rarely did these problems threaten the viability of the state. This partially explains why, internally, Western governments preferred to rely on the police instead of the military against those opposing the established order. $^{70}$

In addition to the dichotomy between external military threats and internal crime problems, another factor mitigated against maximum force in the domestic realm: the democratic norm of using minimum force against citizens. The Cold War coincided with the consolidation of liberal democratic rule in the Euro-Atlantic area, as well as the - albeit uneven and incomplete - spread of democracy to other parts of the world. 
Several features of democracy reduce the likelihood of the domestic use of military force. The constitutions and laws of democracies emphasise the rule of law and norms such as proportionality. Restrictions also exist because decision-makers depend on public support. The disproportionate use of force against citizens - which would be a likely outcome of military intervention, due to military characteristics - would undermine public support. Democracy also reduces the likelihood of domestic military intervention because of institutional checks and balances. Political parties, especially those in the opposition, will want to ensure that the government respects constitutional provisions regarding the deployment of the military. The same holds true for the judiciary, ombudspersons, the media, NGOs, academia and other statutory and non-statutory oversight bodies.

Hence an external military threat and democracy are conducive to keeping the military out of the internal security realm, and in extension to police-military specialisation. ${ }^{71}$ Yet these two conditions are neither necessary nor sufficient. Specialised forces (under different names than the modern terms 'police' and 'military') have always existed, even during internal crisis and in dictatorships. After all, police have a competitive edge against political opponents and ordinary criminals, and soldiers against those resorting to high-end collective violence. Moreover, autocracies (and weak democracies) may refrain from using the military internally because of concerns about legitimacy. In early nineteenth-century England politicians came to understand that heavy-handed military tactics would cause casualties, and the reputation of the military and the state might suffer as a consequence. ${ }^{72}$

Even in liberal democracies, external and internal, and police and military, tasks are not clear-cut. As shown below, three of the four states discussed in this paper have, over recent decades, drawn on military capabilities against internal opponents. ${ }^{73}$ Democracy does not stand in the way of militarised policing, either. Indeed, democracy may spur such policing, as military deployment is often not feasible. In the wake of the 1972 terrorist attacks on the Munich Olympic Games, the West German government created a new paramilitary police force. In Northern Ireland the replacement of the military as the lead security actor by the Royal Ulster Constabulary (RUC) in 1976 accelerated the militarisation of the latter. 
This discussion underlines that liberal democracies face similar constraints. Yet the boundaries of the acceptable are broad. Liberal democracies' institutions governing the use of force differ markedly. Formal rules may create decentralised police structures, bar governments from deploying non-state police officers abroad, prohibit placing the police under military command or troops under multinational command, hinder using military forces for supporting foreign police forces or forbid the targeted killing of suspects.

To this one must add informal rules that impose restraints on the use of force; these overlap with, and are often indistinguishable from, formal rules. Informal rules result from historical experience: as national historical trajectories differ, so do informal rules governing force.

Institutions influence the use of force in two steps. First, they influence the way states construct a problem. Second, and partially resulting from the construction of a problem, states rely on specific levels of force. After declaring a global war on terror, the Bush administration relied predominantly on maximum military force. European states, by contrast, saw terrorism primarily as a law enforcement problem, and therefore gave priority to policing methods. ${ }^{74}$ As the discussion below shows, some states' institutions are more conductive to the use of versatile force abroad than others.

One of the main problems of states in using versatile force is a possible increase in physical risk. All democratic governments are casualty averse. Due to declining birth rates in many rich countries, losses in life arguably weigh particularly heavy. Also, democratic governments are under public pressure to justify each single loss, whereas autocracies find it easier to ignore public criticism and punish critics. In international intervention, democracies therefore prefer to err on the side of caution, such as by deploying combat troops rather than non-armed police officers.

But within these boundaries, states have several options for dealing with the problem of casualties. ${ }^{75}$ Governments may eschew the use of force altogether, so as not to expose security forces to danger. They may also rely on maximum force. High-altitude bombing and long-range artillery fire are less risky than conducting foot patrols through villages infiltrated by insurgents. States may also de-emphasise force protection, applying versatile force and working among the population. The way states manage risk results from their domestic institutions. 


\section{Domestic institutions of intervening states}

This section examines domestic institutions of the US, UK, Germany and Italy governing the use of force in international intervention. ${ }^{76}$ The analysis shows that the US and Germany are less disposed towards the use of versatile force than the UK and Italy.

\section{United States}

US formal rules impose some restrictions on versatile force. Domestically, the Posse Comitatus Act, which dates back to the aftermath of the US Civil War, limits the direct role of the armed forces in fields such as public order, border control and drug enforcement. ${ }^{77}$ Soldiers cannot investigate crimes, execute search warrants or arrest suspects; such operations must be led and carried out by the police. Still, the military does play a role within the US. Under exceptional circumstances, such as when a US state cannot cope with lawlessness or insurrection, the president can deploy regular military troops. Domestic deployment invites versatility, as maximum force is not a feasible option against citizens. The military was deployed, among other occasions, during 1992 riots in Los Angeles, when the federal government drew on US Marines. Moreover, the coastguard routinely conducts law enforcement and crime investigation tasks.

The US military also plays an important indirect role in counter-crime and counterterrorism efforts at home and on US borders, by reinforcing police forces through the use of military weaponry and technology to keep out illegal immigrants and stem the flow of drugs, especially across the USMexican border.

Much more common than the use of regular troops has been the deployment of the National Guard. During the race riots and demonstrations against the Vietnam War in the 1960s, the National Guard was deployed many times. It was also pitched against domestic producers of illicit drugs. Moreover, it intervened to establish public order, such as during the 1992 riots in Los Angeles, after 9/11 and after Hurricane Katrina in 2005. Based on a militia tradition, the National Guard is primarily under the control of the respective state. But under exceptional circumstances the US federal government can draw on the National Guard for domestic operations. 
Abroad, the US has had a penchant for maximum force, using it not only in large wars but also in smaller wars, such as the many interventions in Latin America undertaken as part of the fight against communism. Reliance on maximum force was evident during the early stages of the Vietnam War: the US military rejected British advice that put police forces at the centre of efforts to defend villages against the Vietcong in order to enhance the government's legitimacy and criminalise the insurgency. ${ }^{78}$

In operations below the threshold of war, the US had problems with versatile force, too. One example was the bogged attempt by Delta Force to rescue US hostages in Iran in 1980. Another is the reluctance of large elements within the military to become involved in drug control, ${ }^{79}$ due to concerns that a direct US military role in this would undermine the readiness to fight wars or lead to corruption. The US therefore preferred having foreign forces in the first line against drugs, and consequently stepped up support especially for Latin American security forces (although covert and clandestine US operations continued, as did joint operations with allied forces).

Such support built upon a long tradition. ${ }^{80}$ US foreign policy did include elements for strengthening human rights, democratic oversight and minimum force. But often such efforts took a back seat behind programmes intended to reinforce client states. In many cases, forces trained and materially equipped by the US violated human rights. ${ }^{81}$ As these violations became more visible, domestic concern within the US gave rise to prohibitions of US assistance to security forces abusing human rights. But by limiting the role of the State Department, these prohibitions inadvertently strengthened the role of the Pentagon. ${ }^{82}$

The military was not the only institution applying or exporting versatile force. During the Cold War the Central Intelligence Agency (CIA) made and unmade governments around the world, acting primarily via proxy forces. After the demise of the Soviet Union it expanded its remit, focusing on organised crime, nuclear proliferation and, since the late 1990s, terrorism. The agency created paramilitary units deployed for high-risk tasks. It would also apply maximum force, such as by directing drone attacks on suspect terrorists. ${ }^{83}$

US police forces have much experience in applying varying levels of force, too. Domestically, the 'war on drugs' spurred the creation of paramilitary police units below the federal level. ${ }^{84}$ Federal law enforcement 
agencies use force, too, at times working shoulder to shoulder with the military, as during the 1993 siege of a sect in Waco, Texas. Internationally, a panoply of federal law enforcement agencies has been involved in efforts against drug trafficking, terrorism and other security risks. The Drug Enforcement Administration (DEA), the Federal Bureau of Investigation (FBI) and other federal law enforcement agencies worked alongside the US military and intelligence agencies, with most agents deployed to Latin America. ${ }^{85}$ The Department of Justice's International Criminal Investigative Training Assistance Program has been a prominent promoter of US policing practices to countries around the world. The 9/11 attacks accelerated the fusion of military, police and intelligence work.

The US policing structure is largely decentralised, however, with around 20,000 state and local police agencies. Rules bar the federal government from deputising state and local police officers for the federal role of participating in international intervention. The State Department works around this restriction by outsourcing the selection, training and deployment of US police officers for police missions abroad to private companies, especially DynCorp and Military Professional Resource (MPRI). ${ }^{86}$ But outsourcing has not led to the timely deployment of police officers who possess requisite skills. This shortcoming has added pressure on the military to become involved in policing.

To regulate the use of force abroad, US administrations have instituted important changes since the end of the Cold War. In 1991 President George Bush saw the US as a global policeman exporting democracy as part of the new world order. This role implied a broadening of security practices and priorities, including greater US participation in peace operations. To adapt to new missions, the US military changed its doctrines, strategies and tactics. Thus the 1995 concept of 'military operations other than war' replaced the older concept of small wars, and was followed, in the new millennium, by again newer doctrines. ${ }^{87}$ Restraint and proportional use of force are at the core of all of these doctrines.

However, putting this principle into effect proved difficult, as US historical experience created informal rules that led decision-makers and security forces to give priority to maximum force. Ever since the Vietnam War, the US government (particularly the Pentagon) and public have been wary of foreign quagmires. The painful experience in Somalia in 1993, when 18 US Rangers who had been sent out to capture a wanted warlord were 
killed, reinforced the Vietnam trauma and the fear of military 'mission creep'. Reflecting this fear, the Powell-Weinberger doctrine made US military involvement abroad dependent upon conditions such as clear political objective, decisive victory, an exit option and threats to vital US interests. The 1991 Gulf War fulfilled these conditions, but peace operations risked violating the lessons of Vietnam and Somalia. In Bosnia, Haiti and elsewhere, US decision-makers were therefore adamant that the 'Mogadishu line' must not be crossed. They emphasised force protection, to be achieved through the threat and use of maximum force.

In the new millennium, in Iraq and Afghanistan, the US had no choice but to put into practice the messy and risky logic of COIN (counterinsurgency), as vital interests were seen to be at stake. The COIN concept underscored the importance of the rule of law, legitimate local security forces, minimum use of force to protect the population and win hearts and minds, and avoidance of civilian casualties. But this strategy implied great risks to troops, and thus clashed with US informal rules governing the use of force.

\section{United Kingdom}

The United Kingdom holds capabilities that render it a major power in international affairs. During the Cold War, British defence policy was focused on the Soviet Union; but the UK also successfully waged war against Argentina in 1982 and participated in the 1991 Gulf War. In addition to employing maximum force, the UK has much experience with versatile force. Formal and informal rules facilitate such versatility.

Domestically, military intervention became the exception during the nineteenth century. Even if heavy-handed measures were directed primarily against the lower strata of society, such measures carried practical costs. The government therefore preferred using the police for internal security matters. Indeed, the UK is credited for having created, in 1829, the first modern police force. The British Army retained a domestic role, though, such as during the 1926 General Strike.

Outside its core territory, the British government was less circumspect. In Ireland police forces took the lead against Fenians, relying on heavy-handed measures. In British India, police and military tasks were for long periods indistinguishable. ${ }^{88}$ The Crown employed the military to 
wage war in frontier zones, put down rebellions and establish public order. Sometimes the British used maximum force indiscriminately, most infamously during the Amritsar massacre in 1919. Britain also created paramilitary forces employed for a variety of tasks. Then, during the wars of decolonialisation, as in Malaya, Britain tried to deprive insurgents of their legitimacy through close police-military relations and awareness of minimal force. It must be noted, however, that maximum force was often used, and British counterinsurgency practices were incompatible with contemporary notions of the rule of law and proportional force. ${ }^{89}$

In the fight against insurgents, terrorists and other declared enemies of the UK, covert operations played a major role. Thus the Special Air Service (SAS) staged operations in numerous countries. ${ }^{90}$ In conducting foreign operations, British security forces benefited from the special relationship with the United States and also leveraged relations with security forces cultivated during colonialism.

In recent times, it was in Northern Ireland where the UK learned important lessons on the use of force. Until the late 1970s the British Army was responsible for security in the province. But in its fight against the IRA, the British military sometimes used force inappropriately, most dramatically during Bloody Sunday in 1972. Even after 1976, when the RUC became the prime actor for policing Northern Ireland, the military kept 20,000-30,000 troops in the province and cooperated closely with the police and intelligence agencies. Many critical operations against the IRA were not led by regular military units or the RUC, but by British special military forces and intelligence teams. Regular RUC officers were generally kept in the dark about these operations. ${ }^{91}$ Assessments of the performance of British security forces in Northern Ireland vary. Some charge British forces with having used disproportional force, ${ }^{92}$ while others argue that discriminate targeting facilitated the peace process of the 1990s. ${ }^{93}$

The UK's legal framework facilitates the use of versatile force. Formal and informal rules governing the use of force are not clearly separated, since the UK does not have a formal constitution, relying on royal prerogative instead. Nevertheless, concepts such as military aid to the civil authorities and military doctrines give the British military an important domestic role. This role is largely subsidiary, to help the police establish public order, provide security during internal emergency and move against terrorists and other dangerous suspects. Under exceptional circumstances, 
soldiers can act on their own, without the request of a civil power, such as when only immediate intervention can protect life and property. ${ }^{94}$ The government has frequently deployed the British Army, for example to avert terrorist attacks. Close police-military cooperation and flexible command arrangements facilitated domestic military operations. During the 1980 siege of the Iranian Embassy in London, the SAS operated under the authority of the London Metropolitan Police (for each of the armed men killed, an investigation was conducted to find out whether the SAS had used proportional force). The terrorist attacks on the US in 2001 and on London in 2005 fostered close cooperation among specialised police institutions such as the Serious Organised Crime Agency (SOCA) and the Scotland Yard Counter Terrorism Command, the military and the intelligence services.

In multilateral peace operations, for a long time the UK clung to the principles of traditional peacekeeping, emphasising consent, impartiality and minimum force. The UN Protection Force (UNPROFOR) experience in Bosnia led to adjustments, yet these were initially cautious: the concept of 'wider peacekeeping' was an attempt to prevent the slip from peacekeeping to peace enforcement. ${ }^{95}$ This restrictive doctrine gave way, in 1998, to Joint Warfare Publication 3-50, which introduced the concept of impartial peace enforcement. Assuming potential lack of consent, it allowed greater use of force than older doctrines, although force had to be discriminate, proportional and used as a last resort. In contrast to other countries' military doctrines, the British doctrine presented activities such as crowd control and the arrest of war criminals as military tasks. ${ }^{96}$

For the UK, maximum force has always been an option - the warrior spirit is inculcated in the British Army as much as it is in the US military. But from the conflicts in former colonies and Northern Ireland the UK drew the lesson that small wars are fought over political legitimacy. Troops therefore had to develop positive rapport with the population, which in turn required the avoidance of disproportional force. Also, the military hierarchy had to be sufficiently flexible to give soldiers, particularly non-commissioned officers, autonomy in deciding how to fight what have been named 'corporals' wars'. As shown in the next section, the UK has tried to apply these lessons in cases of multilateral intervention.

In applying or exporting the minimum use of force as understood by the police, the UK, like the US and Germany, is hampered by a decentralised policing structure. British police officers, who are needed at 
home, cannot be easily deployed abroad. Nevertheless, the UK has contributed significantly to civilian policing. It played a major role in developing the paradigms of community and intelligence-led policing, which police agencies around the world have come to embrace. ${ }^{97}$ In international intervention, British personnel often operate in crucial intelligence-related positions.

\section{Germany}

Of the four countries studied in this paper, Germany has had most difficulties using force. This is because of the peculiarities of German institutions, which have been shaped to a major extent by the critical juncture of the Second World War as well as incremental developments thereafter. After the Cold War, Germany participated in ever more international interventions. While these taxed post-war German institutions, no radical institutional overhaul occurred. German institutions continue to impede Germany's ability to use force abroad.

Before the Second World War Germany, similar to other countries, often deployed soldiers domestically. For example, the military cracked down on revolutionaries in 1848, and after the First World War soldiers killed civilians on German streets. The Third Reich featured a large number of military, paramilitary and police forces; distinctions between inside and outside, and police and military tasks, were blurred. These experiences, and Allied restrictions following the Second World War, led the Federal Republic to be circumspect with the domestic use of military force. The Bundeswehr was created in the 1950s, and initially did not have domestic powers. In case of a national emergency the (Western) Allies would take action, also to protect their own troops stationed on West German soil. In 1968 the grand coalition amended the German Constitution/Basic Law (Grundgesetz), passing a law on national emergency that abolished Allied reserve powers. This law allowed the curtailing of civil liberties in case of a national emergency and authorised the federal government to draw on the Bundeswehr and the Federal Border Police (Bundesgrenzschutz - BGS) to avert an imminent threat to the federation, a Land or the democratic order (Articles 87a and 91 of the Basic Law). For this to happen the circumstances had to be extraordinary, such as when a Land was unwilling or unable to avert a threat to its existence emanating from insurgents. In practice, the 
role of the Bundeswehr in domestic policing was insignificant. The terrorist Red Army Faction, for instance, which from the 1970s to the early 1990s was responsible for several high-profile attacks, never succeeded in sparking a mass uprising, which might have required and triggered domestic military action.

After the Cold War some policy-makers and pundits called for extending domestic military powers. But caution prevails, as indicated by a 2006 ruling of the Federal Constitutional Court barring the government from ordering the military to shoot down a plane carrying civilian passengers captured by terrorists. In comparison to the militaries of other countries, the German military lacks powers such as for supporting police during major public events. Military doctrine, enshrined in 'white books', hardly deals with the domestic use of force.

Abroad, too, the German military had little experience with the use of force when the Cold War ended. After the Nazi era German policymakers and the public espoused the idea that war was never again to be waged from German soil. Consequently, the remit of the Bundeswehr was restricted to external defence; this restriction, although somewhat relaxed in 1968, was also intended to alleviate fears of harm inflicted on the German population, which was divided over remilitarisation. During the Cold War the Bundeswehr prepared for defending the country against the Warsaw Pact, while the government tried to prevent war. The Bundeswehr never had to use maximum force in earnest, and the use of versatile force as part of counterterrorism or counterinsurgency was not on the table.

When the Cold War ended, policy-makers and analysts expected Germany to revert to pre-Second World War power politics. ${ }^{98}$ But German formal and informal rules governing the use of force were resilient. Germany stayed committed to multilateralism and continued to avoid the use of force. This stance was obvious during the 1991 Gulf War, when Germany abstained from fighting while footing some of the bill.

Post-Cold War peace operations challenged Germany's tradition of avoiding the use of force. In 1994 the German Constitutional Court ruled that the Basic Law allowed for German participation in peace operations outside NATO territory. In the Balkans, Germany deployed significant numbers of troops into a semi-hostile environment for the first time since the Second World War. On Kosovo, German politicians even referred to the Holocaust to justify military intervention, although this intervention 
violated international law due to the lack of a UN Security Council mandate. Moreover, to be better prepared for small wars and emergencies, Germany restructured its military, and in 1996 it placed special military forces on a firm footing with the creation of the Special Forces Command (Kommando Spezialkräfte-KSK).

Germany tried to reconcile the demands of complex peace operations with its institutional constraints, such as by avoiding the deployment of troops to the most risky areas within a host country. Also, the Bundeswehr prioritised show of force: ${ }^{99}$ deterrence was to protect German forces and avoid situations where German soldiers would attack others. This emphasis on deterrence resembled the Cold War strategy of threatening force in order to avoid having to use it. The fact that the German federal parliament had a great say over foreign military missions added to the government's caution in planning and implementing such missions.

In contrast to the military, German police had more experience with versatile force. After the Second World War most German police forces were placed under the authority of the German states (the Länder), following a pre-war tradition of decentralised policing. The Länder commanded garrisoned police forces (Bereitschaftspolizei) for CRC and SWAT-like units for high-risk operations. On the federal level, the BGS (later renamed Bundespolizei, or Federal Police) was created in the early 1950s are a precursor to the Bundeswehr. It was tasked to help defend the eastern border against a communist attack and put down domestic uprisings, and was given requisite weapons and training. Only in the early 1990 s did the BGS lose its status of combatant. Its best-known unit is the GSG9, an elite police unit created after the terrorist attacks on the Munich Olympic Games in 1972 and deployed numerous times since.

Yet while German police have much experience in scaling up the use of force at home, they have little experience in less permissive foreign environments. The GSG9 has occasionally operated outside of Germany, most famously in 1977 when it liberated hostages from a hijacked plane in Somalia. After the Cold War its remit was extended, to include tasks such as the protection of German embassies in war zones and operations against pirates and kidnappers. But elite units are outside the mainstream of Germany's policing culture. In 1989 West Germany deployed its first police officers to a peace operation (in Namibia); since then, German police have 
been sent to many countries. But Germany has been reluctant to deploy or support militarised police in multinational operations.

This reluctance results from both the informal rule to avoid the use of force abroad and formal institutional structures. German policing is largely decentralised. Under an arrangement between the federal government and the Länder, most officers deployed as part of multilateral operations are Länder police. They are generally risk averse, and so are their superiors within police departments and ministries. Moreover, in wartorn countries, police militarisation often implies close relations between the police and the military. But German law is interpreted as obliging the government to separate police and military functions. ${ }^{100}$ One important consequence is that German police cannot be placed under military command.

Italy

When the Cold War ended, Italy was a regional power, but its political instability and economic malaise did not leave the armed forces unaffected. Still, the Italian armed forces, which since 2000 no longer draw conscripts, have had significant means to project power within Europe, although less so globally. Italy has tested the prowess of its armed forces in several international interventions. The geographical focus was on the Balkans, due to historical ties, the proximity to Italy, the impact of war and crime in the Balkans on Italian security and links between Italian and Balkan organised crime groups.

In comparison to the US and Germany, Italy has a competitive edge in the application of versatile force. One reason for this is the experiences of the Italian armed forces in law enforcement. The armed forces' mission of protecting the national territory is generally understood as including defence against internal threats. ${ }^{101}$ Internal military operations go back to the nineteenth century, when the military played a prominent role in the unification of Italy. Subsequently the government often drew on military support, especially in the south, where many citizens regarded Italy's political institutions and security forces as dominated by the north and alien to southern traditions. Among others, the mafia had much to fear from northern dominance. The mafia had its hardest time during the reign of Mussolini, who regarded the mafia as competition and ruthlessly 
attempted to destroy it (and, under the guise of fighting crime and disorder, any political opponents).

The Cold War saw occasional internal military operations, and these continued after the end of the war. Indeed, the Italian government drew on military support for domestic operations more than many other Western states. ${ }^{102}$ In 1992, following the murder of two judges by the mafia, the government sent the army to Sicily. Other more recent instances included the 2008 decision to deploy paratroopers to the Southern Campania region to support the fight against another organised crime group, the Camorra. ${ }^{103}$ Military operations were not confined to the south: in the same year of 2008 the Berlusconi administration deployed significant numbers of troops to the streets of several Italian cities, to underline the government's determination to stem street crime and illegal migration. ${ }^{104}$

Yet Italy's main asset for versatile force is the Arma dei Carabinieri. Over 100,000 strong, the Carabinieri were created in the nineteenth century, modelled on the French Gendarmerie Nationale. The Carabinieri are a police force with military status, and can be placed under the command of both the Ministry of Interior and the Ministry of Defence. This hybridity finds expression in the use of force: the Carabinieri use minimum force and serve as the Italian equivalent of community police officers. They can also apply intermediate force, such as during riots, and even have light infantry units deployed for counterterrorism and other high-risk tasks. The Carabinieri have been gathering experience in versatile force since their inception, mainly within Italy. Since the end of the Cold War they have also become a small, although vital, element of Italian foreign operations. ${ }^{105}$

In addition to the regular military and the Carabinieri, the Italian government commands further law enforcement institutions that are able to ratchet up or down levels of force. The Guardia di Finanza (Financial Police), for instance, is part of the Army but under the authority of the Ministry of Economy and Finance. It includes not only investigative units but also units that apply force if necessary, given its role in the fields of organised crime, public order and border protection. Paramilitarisation also affects the Polizia di Stato (State Police), which has units for high-risk operations, and to a lesser extent the Polizia Municipale, which enforces the law at the level of communes.

Formal rules give the Italian military a significant role in internal security. This role is subsidiary, placing primary responsibility for domestic 
operations in the hands of the police. As the examples above indicate, it is common practice for the Italian military to support civilian authorities, including in the field of law enforcement and public security. The status of soldiers deployed for domestic operations varies, and includes active military status and the status of 'public security agent'; in the latter case, soldiers act as police. ${ }^{106}$

Due to the large number of Italian security forces and their similar remit, command structures are convoluted. Nevertheless, the ability of different forces to work together domestically, and under the command of different ministries, gives Italy a competitive edge in international intervention. There is much competition among Italy's security forces; but many Italians regard such competition as positive, as it enhances the quality of policing through better responsiveness and mutual control. ${ }^{107}$ Another advantage is the centralisation of some Italian police forces. This makes it easier for the government to deploy police abroad, especially Carabinieri officers. Moreover, the use of Carabinieri abroad leaves smaller gaps in domestic policing than is the case in other countries with gendarmerie forces as well as many countries that do not have such forces.

With regard to informal rules, Italy has few qualms about versatile force. Indeed, it is a keen exporter of versatile policing, with the government emphasising the competitive advantages of the Carabinieri. There is a general impression within NATO and the EU that the Carabinieri have made a significant contribution to multilateral operations. They are therefore in high demand, and their presumed success has bolstered calls for adding more gendarmerie forces to foreign missions. 


\section{LEARNING FROM EXPERIENCE}

This section analyses the use of force by the US, the UK, Germany and Italy in Bosnia and Herzegovina, Kosovo and Afghanistan. While there are many similarities, there are also differences in the way the selected states have used force.

\section{Bosnia and Herzegovina}

The 1992-1995 war in Bosnia was Europe's bloodiest conflict since the Second World War. After the 1995 Dayton Accord ended the fighting, NATO's Implementation Force (IFOR) moved into the destroyed country in January 1996, in the then largest NATO operation ever. Bosnia and Herzegovina was no longer at war, but in the immediate aftermath of Dayton there was no peace either. As it turned out, sending countries struggled with the violence and crime that undermined security in postDayton Bosnia and Herzegovina. The Dayton Accord was precise on military matters, such as the separation of enemy forces and the control of heavy weapons; but it did not clearly specify the obligation of the military to lend support on issues that required versatile force, especially the arrest of suspected war criminals, support to the police, public security and the reform of Bosnia and Herzegovina's intelligence agencies. ${ }^{108}$

Because of problems with the police, much depended on a proactive military. The UN International Police Task Force (IPTF) deployed late; its officers were unarmed and did not have an executive mandate; the mission 
comprised staff from numerous countries; and some IPTF officers lacked police skills. Even worse, the mission depended on the cooperation of domestic police forces, even though many of their members were ethnically biased and continued to abuse human rights. Unfortunately, military support to the IPTF was not always forthcoming. While the Dayton mandate did not prevent troop-contributing countries from engaging in policing, a lack of political will, as well as problems with training, equipment and organisation, stymied military activism. National contingents often dealt with these problems in different ways.

\section{The use of force by the United States}

IFOR totalled around 60,000 troops, most of whom came from the US. The US also contributed the largest contingent to the successor mission, the Stabilization Force (SFOR). European states had been unable to put an end to the Bosnian war, and the US was determined to avoid a relapse to war following the Dayton Accord, which had been imposed on the country under US leadership. Post-Dayton Bosnia and Herzegovina was divided into three sectors (or multinational divisions), and US forces held command over one of these (the other sectors were under the command of the UK and France, respectively).

US troops faced no systematic resistance when they began to implement the military aspects of Dayton. Consent was not a given, as Bosnia and Herzegovina counted around 400,000 former combatants, many of whom, especially on the Bosnian Serb side, were hostile to NATO. Concerns about force protection weighed heavily on US decision-makers, for the historical reasons described above and because the UN's failure to stop the Bosnian war added to a cautious US attitude towards multinational peace operations. ${ }^{109}$ One consequence was that US troops were initially deployed for one year only, with President Clinton then having to convince Congress time and again to extent the mission. Moreover, US civilian and military decision-makers took a narrow view on the Dayton mandate, focusing on core military aspects only.

This stance impacted on international stabilisation efforts more generally. Many security problems in Bosnia and Herzegovina did not clearly constitute a violation of the military aspects of Dayton, but they did perpetuate public insecurity. The US reluctance to use force unless 
challenged showed as early as 1996, during the evacuation of Serbdominated areas in Sarajevo. As houses burned and thugs threatened those citizens who did not want to leave, IFOR troops were watching. ${ }^{110}$ The failure to intervene damaged the reputation of international actors in the eyes of many citizens of Bosnia and Herzegovina for years to come.

The use of versatile force remained difficult over the following years. US troops were not equipped and trained for CRC, even though the risk of crowd violence was constantly present. The risk was especially high when displaced persons tried to return to their former homes in areas dominated by another ethnic group (enabling such returns was one of the main objectives of international actors in post-Dayton Bosnia and Herzegovina). One particularly violent incident occurred on 28 August 1997 in Brčko, when supporters of Radovan Karadžić attacked international staff. SFOR soldiers from the US had the authority to use live ammunition to disperse crowds, but instead they used their fists and rifle butts against demonstrators, some of whom were women and children. When rioters threw a Molotov cocktail, troops used tear gas for the first time in Bosnia and Herzegovina. ${ }^{111}$ This incident was cataclysmic, underlining the need for systematic versatile force. Following the incident, non-lethal weapons were made widely available to US troops, ${ }^{112}$ although they would still not receive systematic training in CRC.

Another problem revealing US travails with versatile force was the presence of paramilitarised local police forces. These forces manned checkpoints, intimidated the population, particularly members of other ethnic groups, and tried to prolong their policy of 'ethnic cleansing'. US troops that were part of IFOR and the first rotations of SFOR were reluctant to threaten or use force against these paramilitaries, and therefore often failed to confiscate their weapons and documents and dismantle illegal checkpoints. ${ }^{113}$ As a matter of force protection, the US relied on show of force, making it clear that if US troops came under attack, the response would be swift and decisive.

The US fixation on maximum force (which was only a feasible option where international troops came under attack) was even more pronounced in another area: the arrest of suspected war criminals, or 'persons indicted for war crimes' (PIFWCS) by the International Criminal Tribunal for the Former Yugoslavia (ICTY). The ICTY lacked the means and the mandate to arrest suspects, and therefore had to rely on troop-contributing states. 
However, IFOR commanders from the US asserted that IFOR did not have the right to arrest anyone or, alternatively, that there was no military value in doing so. ${ }^{114}$ In interpreting the military mandate, the US gave priority to force protection. NATO troops were therefore told that they should make arrests only if they came across suspects in the course of their normal duties. As NATO forces were not actively looking for suspected war criminals, and as the latter were not keen on crossing the path of NATO forces either, de facto impunity was given to the perpetrators of the Bosnian war.

Despite much international criticism, US decision-makers remained faithful to their policy of avoiding situations that would pose significant risks to troops and did not obviously violate the military aspects of Dayton. US military leaders emphasised as late as August 1997 that US troops would not participate in arrest operations. ${ }^{115}$ It took until early 1998 for the US to take the lead in an operation to arrest a suspected war criminal. ${ }^{116}$

By the late 1990s, as Bosnia and Herzegovina became safer, US decision-makers better understood the need for versatile force. 9/11 boosted this shift in thinking and practice. The role of Bosnia and Herzegovina as a terrorist sanctuary has been disputed and exaggerated. ${ }^{117}$ Nevertheless, after 9/11 US forces conducted ground and aerial patrols to spot any (Wahabi) terrorist cells and terrorist training camps. ${ }^{118}$

In addition to its executive role in Bosnia and Herzegovina, the US supported domestic security forces. In doing so, it relied much on private security companies. MPRI bolstered the armed forces of the Federation (which raised fears among Bosnian Serbs), while DynCorp was contracted by the State Department to add personnel to the IPTF.

At the beginning of the new millennium, DynCorp became mired in a scandal surrounding the involvement of staff in the trafficking of women for sexual purposes (not only DynCorp staff were allegedly involved, however). ${ }^{119}$ The boom in human trafficking, which would not have occurred in the absence of the large number of well-paid foreigners, is an extreme example of the nefarious side effects of international intervention. But the response, after much initial denial, also underlined the shift to versatile force: in 2002 the IPTF, under US leadership and together with domestic police, conducted hundreds of raids on brothels and bars in order to show that human trafficking would not be tolerated. 
The use of force by the United Kingdom

The UK was one of the three countries commanding a military sector in Bosnia and Herzegovina. British IFOR troops started operating in Bosnia and Herzegovina right after Dayton, and in some of the most hostile zones. With 13,000 troops, the UK was the second-largest contributor to IFOR after the US. The UK was ready to use maximum force to avert any threats to the military aspects of the Dayton Accord. For this, the UK deployed primarily combat forces.

When compared to the troops of other countries, the British Army had a competitive edge in Bosnia and Herzegovina, stemming from the export to Bosnia of lessons learned in Northern Ireland. ${ }^{120}$ One of these lessons was that the collection of intelligence and close police-military cooperation were preconditions for success. ${ }^{121}$ As three intelligence experts write, in Bosnia and Herzegovina large proportions of regular British Army soldiers 'were devoted to intelligence and even during mundane operations each soldier was regarded as an intelligence collector'. ${ }^{122}$ Another lesson regarded versatile force. In contrast to the US, the UK was less reluctant to arrest suspected war criminals. On 10 July 1997 British troops arrested a suspect, and killed another person resisting arrest. The operation, which was carried out by the SAS, ${ }^{123}$ was highly symbolical, as it indicated a growing international consensus to enforce the decisions of the ICTY. Subsequently, British special military forces staged further interventions, underlining the willingness and ability of the UK to use versatile force. British troops were also more proactive than US troops in forcing recalcitrant domestic police officers to comply with Dayton. ${ }^{124}$

In the new millennium, the British Army added further facets to its activities. In 2004 the European Union Force (EUFOR) replaced NATO's SFOR; the previous year, the European Union Police Mission (EUPM) had replaced the UN's IPTF. A British general, David Leakey, was the first commander of EUFOR. Leakey interpreted his mandate to support the EU's mission implementation plan in a broad manner. His rationale was that organised crime posed an obstacle to peace and stability in Bosnia and Herzegovina, and that the police did not have the clout to put pressure on organised crime groups and depended on the military to this end. Indeed, domestic police forces during EUFOR's first mandate suffered from the political fragmentation of the country, a lack of political will and capacity, 
and corruption. The EUPM initially did not have a mandate to fight organised crime and was given insufficient guidance and equipment from Brussels. ${ }^{125}$

EUFOR tried to fill the gap, such as by staging operations against illegal logging and stepping up the control of Bosnia and Herzegovina's porous and rugged borderlands. ${ }^{126}$ Officially, as in Northern Ireland, the military acted in a subsidiary role. Leakey was keen to avoid drawing EUFOR soldiers into tasks such as handling evidence or testifying in court; he wanted the soldiers to discover crimes, secure the area and then allow the domestic police to take over. ${ }^{127}$ But in practice, the difference between police and military tasks was not clear-cut because police work depended on the vastly superior military capabilities to use force. ${ }^{128}$

EUFOR wound down its operations against organised crime as of mid2005, after which domestic police forces, with support from EUPM, increasingly assumed the lead in policing. British police officers played an important role in improving the EUPM's capabilities for strengthening and reforming Bosnia and Herzegovina's police forces, focusing on civilian policing skills. British EUFOR troops continued to be involved in the fight against serious crime, such as by supporting the police in the arrest of suspected war criminals through the establishment of security perimeters and the provision of intelligence. ${ }^{129}$ But the presence of EUFOR troops on the streets and hills of Bosnia and Herzegovina became ever rarer. The command of General Leakey constituted a peak in EUFOR's activism in versatile policing.

\section{The use of force by Germany}

Germany had participated in international efforts to stop the Bosnian war, although legal uncertainty and domestic opposition limited the deployment of ground forces. This cautious attitude also informed Germany's policies towards post-Dayton Bosnia and Herzegovina. It did contribute over 2,500 soldiers to IFOR, but these operated on Croatian territory, venturing into Bosnia and Herzegovina only occasionally (a small number of staff worked within military headquarters in Bosnia and Herzegovina). Germany therefore managed to avoid the stark dilemmas over the use of force that IFOR ground troops from other countries faced. 
When SFOR replaced IFOR, Germany yielded to US pressure to share the burden of keeping the peace in Bosnia and Herzegovina. Germany committed 3,000 troops to SFOR, in the first deployment of German ground troops into an environment that many still regarded as hostile. Similar to the US, German civilian and military decision-makers tried to avoid situations where German soldiers would be drawn into a police-like role. Instead, German troops focused on what they regarded as the core military tasks in Bosnia and Herzegovina. One indicator of this cautious attitude is the fact that several years after Dayton, German SFOR troops still did not possess shields or batons for controlling crowds, and did not receive any training to this effect either, despite an agreement that each national SFOR contingent should have some CRC capabilities. ${ }^{130}$ German forces relied on show of force - similar to practices during the Cold War, show of force was to deter attacks and avoid having to resort to force.

In contrast to regular German troops, special forces did use versatile force. If Germany's military role in Bosnia and Herzegovina was astonishing given Germany's domestic institutions governing the use of force, special forces operations constituted a small revolution. Among other tasks, special forces were deployed for arresting PIFWCs. In June 1998 members of Germany's KSK, together with French special forces, arrested a suspected war criminal in Foča, a town in eastern Bosnia and Herzegovina in which Serb nationalism was strong. ${ }^{131}$ In August 1999 and October 2000 the KSK conducted further operations against PIFWCs. ${ }^{132}$ The risks were high: in one incident, three KSK soldiers were wounded when the suspect detonated a hand grenade.

\section{The use of force by Italy}

Italy deployed combat units to IFOR that contributed to the implementation of the military aspects of the Dayton Accord. Like other IFOR contingents, the Italians were prepared for any military confrontation. After IFOR was replaced by SFOR, and as Bosnia and Herzegovina became safer, Italy restructured its military contribution: while armoured and artillery elements were downsized, it deployed more military police, intelligence and reconnaissance, psychological operations units and special forces. ${ }^{133}$ While such personnel allowed Italy to improve management of challenges that were below the scale of military attacks, there is little evidence that 
the Italian military was particularly apt at applying versatile force (despite having significant powers back home in Italy, as outlined above). One Italian general, who was a senior SFOR officer after Dayton, remarked many years later that the mandate of the Dayton Accord did not cover police tasks. ${ }^{134}$

The outlook of the Carabinieri was different. They were deployed as part of the Multinational Specialized Unit (MSU), created in 1998. The 386 Carabinieri constituted around 75 per cent of the MSU; the remaining MSU gendarmeries came from other countries. ${ }^{135}$ The MSU, which was placed under SFOR command, possessed skills in CRC and counter-crime operations that most SFOR soldiers and IPTF officers lacked. Initially the Carabinieri were hampered by an Italian law prohibiting them from conducting investigations and law enforcement when operating under the Ministry of Defence, ${ }^{136}$ but this problem was quickly resolved.

Italy's allies proved a greater obstacle than Italian law. In a few instances the Carabinieri were able to prove their competitive edge, as when they prevented situations from escalating by communicating with crowds. Generally, however, the MSU lacked effectiveness because regular military officers did not understand its roles and competencies. This was particularly the case with commanders from countries that did not have gendarmerie forces (IPTF officers from countries without gendarmeries shared the military commanders' lack of faith in the MSU). Also, some commanders of multinational divisions resented MSU operations within their area of responsibility. As a consequence, the SFOR leadership frequently used the MSU as a reserve force, for protecting VIPs and for static guard duties. ${ }^{137}$ SFOR thus largely failed to leverage the MSU's skills to prevent a situation from escalating and gather information through patrolling and surveillance.

In spite of these obstacles, the MSU contributed to filling the security gap. Initially its mandate did not cover the arrest of PIFWCs, but after changes to the mandate the MSU became one of the key allies of the ICTY. A main contingent would secure an area, and an MSU SWAT team would make the arrest. In at least one case the gendarmeries also worked in plain clothes in support of the ICTY (the only other actors conducting plainclothes operations were special military forces). ${ }^{138}$

To place police-military cooperation on a firm footing, NATO developed the Blue Box/Green Box concept, which constituted an improvement particularly to CRC not only in Bosnia and Herzegovina but 
also in Kosovo. According to this concept, regular police forces or gendarmeries would hold command over the inner Blue Box and the military over the outer Green Box. The concept rendered the Carabinieri more effective by increasing their operational freedom. One study finds that by the year 2000, the MSU had resolved 261 out of 263 interventions without using force, relying on deterrence and negotiation instead. ${ }^{139}$

To be sure, problems of police-military cooperation persisted, despite the Blue Box/Green Box concept. In April 2001, during riots in Herzegovina, international forces once again proved unable to cope with violence below the threshold of war. This experience led decision-makers to relax further restrictions governing the use of the MSU. One crucial element of change was to allow the MSU to support the IPTF and domestic police forces. ${ }^{140}$

The decision to increase the remit of the MSU put more pressure on ordinary criminals, such as human traffickers, as well as on well-connected politicians suspected of pursuing crime. ${ }^{141}$ The MSU also became more involved in countering any potential terrorist threat, by observing and analysing Islamist groups that might threaten US facilities and SFOR, and providing area security during counterterrorism operations. ${ }^{142}$

Relations between the regular military and the Carabinieri remained strained at times, even after EUFOR replaced SFOR. Similar to their SFOR predecessors, some EUFOR officers complained about the Carabinieri suddenly appearing in their area of responsibility without prior notice, searching for weapons or suspects. Such operations, the officers said, undermined local support for the EUFOR mission, possibly resulting in higher risks for soldiers living among the people. ${ }^{143}$ Generally, however, EUFOR commanders gave the Carabinieri more freedom of manoeuvre than had been the case with SFOR commanders. The Carabinieri, together with gendarmerie colleagues from other countries, were now part of the Integrated Police Unit (IPU), which became the first mission of the European Gendarmerie Force. Moreover, the Carabinieri seconded around 15 officers to the EUPM, a step that forged stronger ties between EUFOR and the EUPM. ${ }^{144}$

Under EUFOR, the Carabinieri, whose numerical superiority gave them the lead in the IPU, promoted the use of versatile force in various areas. They prepared for intervention during public disorder and also trained domestic police forces for this purpose. Moreover, the Carabinieri supported the domestic police in areas such as surveillance and high-risk 
arrest operations against organised crime groups and PIFWCs. ${ }^{145}$ To perform their tasks, the IPU included experts in fields such as special investigations, forensics and counterterrorism. ${ }^{146}$ One of the main recipients of IPU support was the State Investigation and Protection Agency (SIPA), a state-level law enforcement institution. For example, in 2006 and 2007 the IPU supported SIPA in months-long operations against organised crime groups. ${ }^{147}$ The IPU was also instrumental in building SWAT teams within SIPA and training these teams for tasks such as hostage situations. ${ }^{148}$

In cooperating with their domestic partners, the Carabinieri had to tread a fine balance. On the one hand, empowering domestic actors was crucial for promoting local ownership and enabling the eventual withdrawal of international forces. On the other hand, the Carabinieri had to take into account the possibility of domestic security forces or politicians colluding with suspects. In many cases the Carabinieri, whose mandate allowed them to use force in an executive capacity and to operate across Bosnia and Herzegovina, would share only general information about operations with domestic security forces, and only shortly prior to operations. ${ }^{149}$

\section{Kosovo}

In early 1999 NATO went to war against what was left of the Federal Republic of Yugoslavia in an effort to compel Yugoslav President Slobodan Milošević to stop the violence against Kosovars (ethnic Albanians) in Serbia's southern province of Kosovo. After nearly two months of bombing, Milošević gave in. On 9 June 1999 NATO and Yugoslavia signed the Kumanovo Agreement, which stipulated the withdrawal of Yugoslav/Serbian forces from Kosovo and the creation of an international security force, NATO's Kosovo Force (KFOR), which at its peak numbered 50,000 soldiers.

The mandate of KFOR was more precise than had been the case with the Dayton Accord, calling on the military to use force if necessary in policemilitary grey areas. KFOR was to supervise compliance with the Kumanovo Agreement, secure the province's boundaries and borders, enable the return of refugees and establish public safety and order until an international civilian presence, the UN Interim Administration Mission in Kosovo (UNMIK), was able to do so. As KFOR had full tactical policing 
authority, it had to engage in tasks such as the running of prisons, in contrast to IFOR.

UNMIK was based on UN Security Council Resolution (SCR) 1244, which stipulated that until Kosovo's status was resolved, UNMIK would govern the province. If Kosovo was a novel mission for NATO, so it was for the UN. For the first time the UN was responsible for all governance functions in a territory, and for the first time it created a police mission (UNMIK Police) with executive powers.

Numerous countries provided troops to KFOR and police officers to UNMIK Police. When KFOR moved into Kosovo on 12 June, troops were well prepared for fighting the still powerful and battle-hardened Yugoslav army. But instead they faced problems that, as in Bosnia and Herzegovina, called for versatile force.

The early post-war period saw numerous reprisal attacks, most of which were committed by Kosovars against Serbs and other minorities. Killings also occurred among Kosovar factions, with former members of the Kosovo Liberation Army (KLA) suspected of assassinating hundreds of opponents in 1999. The disarmament of the KLA, as stipulated by UNSCR 1244 , was not a given, as former fighters were reluctant to hand in their weapons. Kosovo also consolidated its position as a hub of organised crime, with both Kosovars and Serbs engaging in smuggling and trafficking in human beings and goods, often cooperating with one another across ethnic lines. ${ }^{150}$ Inter-ethnic violence remained a problem, too. In province-wide riots in March 2004, 19 people were killed and hundreds of religious sites, almost all of them Serbian, were destroyed. International actors also faced the challenge of apprehending PIFWCs (the ICTY had indicted both Serbs and Kosovars for war crimes). Even more difficult to tackle, political corruption undermined the prospects of economic revival, as well as the legitimacy of international actors and Kosovo's leadership as seen by the inhabitants of Kosovo. Often, the same persons were suspected of being involved in different types of serious crime - politics, business and crime were inextricably linked, both during and after the war. ${ }^{151}$

Kosovo was thus a test as to whether sending countries had learned from post-Dayton Bosnia and Herzegovina. In some ways, they did. For example, in contrast to IFOR, most KFOR contingents made an effort to contain the anarchy in post-war Kosovo. ${ }^{152}$ But there were parallels between the two international interventions, in that the use of force was 
improvised and intervening states frequently sacrificed the rule of law to (superficial) stability. ${ }^{153}$

UN police arrived late, and UN policing was plagued by a lack of capacity and coordination. There were no reliable local security forces, only remnants of the KLA and, in northern Kosovo, Serbian self-declared security forces such as the 'bridge watchers' of Mitrovica. Relations between KFOR and UNMIK suffered from different chains of command, with KFOR reporting to NATO in Naples and UNMIK to UN headquarters. KFOR was thus not under the authority of the head of UNMIK, who acted as the special representative of the UN Secretary-General. A lack of institutionalised cooperation led to situations where KFOR, in efforts to put a stop to the boom in human trafficking, would raid brothels without notifying UNMIK, whose police were investigating the same brothels. ${ }^{154}$ Even within KFOR there were fissures, with sending states often being guided by national priorities, traditions, capabilities and caveats rather than the orders of the KFOR commander in Pristina. ${ }^{155}$ Along the boundaries and borders, KFOR tried to intercept weapons, but a lack of knowledge in customs and excise practices allowed the trafficking of various goods to continue. ${ }^{156}$ Moreover, both KFOR and UNMIK were unprepared for the establishment of public order. ${ }^{157}$ Even worse, for a long time soldiers, police officers and judicial personnel did not know which laws to pick from the pot pourri of international and domestic laws and directives. ${ }^{158}$

Given these conditions, it does not come as a surprise that sending countries and their security forces used force differently. These differences persisted beyond 2008, when Kosovo unilaterally declared independence and UNMIK was replaced by the EU's rule of law mission, EULEX.

\section{The use of force by the United States}

The United States was the main protagonist in the aerial war against Yugoslavia. After the war, the US provided substantial numbers of troops to KFOR and had command over one of the military sectors in Kosovo (the others were under the command of Germany, the UK, Italy and France, respectively; these states also provided the commanders of KFOR - COM KFOR). ${ }^{159}$ Similar to contingents from other countries, US KFOR was mainly worried about the possibility of Yugoslav troops not honouring the Kumanovo Agreement - there was a sense that Yugoslav troops might try 
to re-enter Kosovo after temporarily withdrawing. The geographical proximity of the US military sector to Yugoslavia exacerbated these concerns.

US troops left no doubt that they were prepared for war against Yugoslav forces should these forces not withdraw from Kosovo or try to stage incursions after their withdrawal. US KFOR therefore included elite combat forces and was given heavy weaponry, such as Apache helicopters and M1-A1 Abrams tanks. However, some provocations and isolated attacks on KFOR notwithstanding, Yugoslavia complied with the Kumanovo Agreement.

As in Bosnia and Herzegovina, it soon became clear that the main security problems in Kosovo fell below the threshold of regular warfare. US troops, like those from other countries, struggled to apprehend perpetrators of crime. Force protection rules were so strict that US troops were not allowed to 'fraternise' with the local population. ${ }^{160}$ Troops also lacked the equipment, training and intelligence for applying less than maximum force.

Yet despite their combat outlook, US troops had to do something about the many acts of violence. On the ground, troops improvised, arresting those they could get hold of. But as soldiers lacked law enforcement expertise, arrest procedures tended to violate police principles and human rights. ${ }^{161}$ Moreover, once an arrest was made, the military faced new problems. As there were no prisons, suspects (reportedly Serbs, Kosovars and terrorism suspects from various countries) were held in the US military camp of Bondsteel (troops from other sending countries often delivered suspects to US KFOR). ${ }^{162}$ The conditions in the prison, and the fact that the US denied human rights monitors access to the suspects, drew much criticism from human rights organisations, which compared Bondsteel to Guantanamo. ${ }^{163}$ As a lack of civilian police skills led to failure to establish a chain of evidence, it was unclear how suspects could be tried. Besides, there was no functional criminal justice system, ${ }^{164}$ and it was unclear which laws applied.

Over the years the US scaled down its military presence in Kosovo and withdrew most of its elite combat troops. Their successors were primarily soldiers from the US National Guard. These were able to fight, too, but they worked more closely with the civilian population, relaxing force protection measures (for example, soldiers on foot patrol wore soft 
caps instead of helmets). ${ }^{165}$ Indeed, US troops engaged in tasks such as escorting Serbs through territory dominated by Kosovars, escorting Kosovars through Serb enclaves and setting up checkpoints (which KFOR often manned jointly with the Kosovo Police Service - KPS, later renamed Kosovo Police). ${ }^{166}$ Moreover, after the March 2004 riots, US troops received systematic training in CRC.

US KFOR also supported the KPS and threw its weight behind the Kosovo Protection Corps (KPC), a civilian emergency service and, in the views of many Kosovars, an incipient army. The institution comprised primarily former KLA fighters and was supposed to facilitate the disarmament of the KLA. In 2008 the KPC was replaced by the Kosovo Security Force, the remit of which was severely circumscribed to alleviate Serbian fears.

Even as security conditions improved in Kosovo, US KFOR remained reluctant to apply force against both perpetrators of serious crimes and ordinary criminals, ${ }^{167}$ as long as these did not threaten US troops. The war on terror did not substantially change US policies towards Kosovo. The US was wary that Kosovars studying at religious schools outside Kosovo might join the Islamist cause. ${ }^{168}$ Yet shady former KLA members turned politicians or businessmen were hardly affected by counterterrorism. Many years after the war, those criticising international actors for failing to promote the rule of law in Kosovo charged particularly the US of failing to apply pressure on former KLA leaders, and even of hampering European law enforcement efforts. ${ }^{169}$

There are several reasons for this cautious US attitude. During the war the US had been the main supporter of the KLA, and wartime ties persisted into the post-war period. Moreover, the US, like other sending countries, was concerned that using force against Kosovo's strongmen would undermine stability - indeed, these strongmen skilfully played the stability card. Strategically, the US relied on cordial relations with the Kosovars to buttress their claims that US policy was not anti-Muslim (a concern raised by the US-led invasions of Iraq and Afghanistan). Also, the Bush administration was adamant that the US would not engage in nationbuilding, and the US military was to fight the nation's wars. 
The use of force by the United Kingdom

The British Army was prepared to fight any Yugoslav forces not complying with the Kumanovo Agreement. British forces were among the first to enter post-war Kosovo, and the UK had military command over one of the sectors (the central sector) into which NATO had divided the province. Moreover, the UK faced the same problems affecting all sending states. For instance, British KFOR troops in 1999 received no legal guidance from KFOR headquarters on how to carry out operations, and as a consequence had to refer to their own British military legal advisers. ${ }^{170}$

As in Bosnia and Herzegovina, British troops applied versatile force more than US forces. Thus the SAS arrested suspect criminals. ${ }^{171}$ The UK also deployed Royal Military Police and military investigators from the Special Investigation branch to the British military sector. Regular forces, too, proved flexible; in Pristina, Mitrovica and elsewhere they applied lessons from Northern Ireland against crime and inter-ethnic violence. ${ }^{172}$ To gain public trust and establish positive rapport with the local population, the UK relied on foot patrols and relaxed force protection measures, retaining the option of using maximum force if necessary. ${ }^{173}$ In 2001, while US troops moved around in heavily armed convoys, British troops were wearing soft caps. ${ }^{174}$

This stance gave British troops an edge against smugglers, too. In one case the US accepted a British offer to try to apprehend weapons smugglers whom US troops had failed to catch because the troops operated in large units using searchlights and armoured vehicles. A small British unit hid in the terrain, and after five days seized a large weapons shipment smuggled into Kosovo from Macedonia. ${ }^{175}$

Even when British forces were not the ones carrying out coercive operations, intelligence provided by the UK often supported, or was a precondition to, such operations. The UK participated in the Quint, the most influential countries in Kosovo. ${ }^{176}$ It also deployed staff to multinational institutions such as KFOR's Joint Intelligence Operations Centre and UNMIK's Criminal Intelligence Unit. Furthermore, British special forces were part of a company-sized intelligence, surveillance and reconnaissance unit that was placed under the command of KFOR and observed persons suspected of being involved in various types of crimes. To achieve their mission, members of the unit used assets that included 
drones as well as tactics such as plain-clothes surveillance. ${ }^{177}$ The unit prepared the ground for arrest operations carried out by SWAT teams of KFOR and UNMIK Police.

\section{The use of force by Germany}

German troops moved into Kosovo immediately after the war, and Germany took command over a large military sector (the southwest). The Germans were prepared for any resistance Yugoslav troops might offer. The first few days into the mission were the most risky. ${ }^{178}$ To prevent any attacks on KFOR and inter-ethnic violence (particularly attacks by Kosovars on Serbs were a problem), German soldiers threatened the use of force and, in a few cases, applied force. ${ }^{179}$ It relied on heavy weapons, such as those of the 12th Tank Brigade.

While stabilising Kosovo's southwest was a risky task, two conditions reduced the risks for German troops. As the sector did not border (the rest of) Serbia, the possibility of an incursion of Yugoslav troops into Kosovo weighed slightly less heavily on German troops than on the troops stationed along the boundary line behind which Yugoslav troops had withdrawn. Moreover, the majority Kosovar population supported the German troop presence. After all, the German coalition government had been one of the main advocates of NATO's aerial war, despite much domestic resistance. ${ }^{180}$ The minority Serb population was obviously less enthusiastic about KFOR in general and German troops in particular.

Subsequent events vindicated the reservations of the Serbian minority. During the initial post-war period troops in the German-controlled sector were often unable to prevent the destruction of life and property of minority groups (although similar dynamics unfolded in sectors controlled by other countries). ${ }^{181}$ Troops on the ground often had no choice but to improvise. Thus by the end of June 1999 they held nearly 100 prisoners in Prizren. ${ }^{182}$ While the German military police proved quite versatile, ${ }^{183}$ regular troops were ordered to stay inside the barracks or use heavy force protection. The Bundeswehr made it clear that maximum force would be used in cases of attacks on German troops. But show of force was inadequate for preventing or stopping inter-ethnic violence. This approach, intended to reduce risks to German troops, was a blunt instrument against smuggling and trafficking of people and goods, too, despite the fact that 
southwestern Kosovo, bordering on Albania and Macedonia, was a hub for crime.

Germany's difficulties in coping with violence dramatically came to the fore in March 2004. Facing thousands of Kosovar demonstrators, German troops simply withdrew into their barracks and waited while Serbian churches and houses went up in flames and UNMIK Police officers had to defend themselves. ${ }^{184}$ The troops clung to very restrictive rules of engagement that allowed use of force only in self-defence; also, they lacked CRC training and equipment.

Following the March 2004 riots, which had a disastrous impact on the reputation of international actors in Kosovo in general and the Bundeswehr (as well as the French armed forces) in particular, Germany modified training, equipment and rules of engagement in Kosovo. Among other measures, German troops were given non-lethal chemical agents, which required amending a law describing Germany's implementation of the international chemical weapons convention.

Over the years, many Serbs left the south and settled in northern Kosovo or Serbia; Kosovo became another frozen conflict. As superficial stability set in, the Bundeswehr became more proficient in scaling up and down the use of force. Despite the official mantra that the police were leading the fight against organised crime, the Bundeswehr staged patrols in border zones. When soldiers came across criminal activities, they would apprehend the suspects and wait for the KPS to make the arrest. ${ }^{185}$ In winter 2011/2012 Bundeswehr soldiers deployed to northern Kosovo found themselves engulfed in the border dispute between Serbia and Kosovo. To contain the violence and respond to attacks, German soldiers employed different levels of force. The Bundeswehr was no longer the same as in 2004 - withdrawing into barracks in the face of violence was no longer an option.

\section{The use of force by Italy}

Italy, like the three other sending states discussed above, was given responsibility for ensuring a secure environment in one of the military sectors into which Kosovo was divided. Security conditions during the initial stage of KFOR's mission were as difficult for Italian troops as for the troops of other countries. Yet cordial relations between Italian troops and the 
majority Kosovar population somewhat reduced force protection risks for Italian KFOR soldiers. Italy gave former KLA members relatively free rein to establish quasi-governmental structures, including in policing. ${ }^{186}$

This cautious stance notwithstanding, Italy fared better in the use of versatile force than some other sending states. This is partially because Italian commanders of regular military forces took a broad view of military duties in Kosovo. For instance, General Fabio Mini, who held the position of COM KFOR in 2000-2001 and was much concerned about the presence of criminals within the KPC, wanted KFOR to take a lead in the fight against organised crime. In his view, the smuggling in human beings, weapons and drugs, political violence and even money laundering posed a threat to a safe and secure environment. ${ }^{187}$

Even more importantly, as in Bosnia and Herzegovina Italy deployed Carabinieri. In MTF-West, which was under Italian command, the Carabinieri supported the Italian military against crime. ${ }^{188}$ Carabinieri also formed the bulk of the MSU, of which Italy was the lead nation. The MSU was modelled on that in Bosnia and Herzegovina and comprised over 300 officers. It was placed under the command of COM KFOR and allowed to operate all across Kosovo, with a mandate in fields as varied as CRC and efforts against organised crime and terrorism.

The Carabinieri were highly proactive in Kosovo. Particularly during the first years after the war, they seized large amounts of weapons, ammunition and smuggled goods, identified criminal groups, raided suspected sites of human trafficking and arrested persons. ${ }^{189}$ The MSU consulted COM KFOR on crime and terrorism, and in Pristina the MSU was directly responsible for security. A former deputy commander of KFOR serving in 2001/2002 states that for high-risk operations against suspected war criminals and members of organised crime groups, he frequently called on the MSU. ${ }^{190}$ Perhaps the most important Carabinieri task was CRC. The MSU became a vital element of CRC scenarios that were improved over the years: they would form a third line of defence, backing up the KPS (the first line) and UNMIK Police (the second line). In case rioters overpowered even the MSU, regular KFOR units (the fourth line) would step in. ${ }^{191}$

The MSU supported a host of institutions within Kosovo, both international and domestic. It provided KFOR's elite intelligence, surveillance and reconnaissance unit with human intelligence and the KPS, UNMIK Police and regular KFOR units with expertise in CRC. ${ }^{192}$ The KPS 
relied significantly on the MSU, which provided intelligence, material support (such as helicopters for aerial surveillance) and training in fields such as weapons handling, forensics and close protection. ${ }^{193}$ The MSU was also present in many arrest operations. In some cases it would apprehend a person and seize weapons, yet leave the formal arrest to the KPS. KPS officers generally relished the MSU presence, as it placed the responsibility for the arrest of individuals who were powerful and/or known to KPS officers on internationals. ${ }^{194}$ Although ties were close between the MSU and the KPS, the former would leave the latter in the dark about the details of sensitive operations - trust only went so far. ${ }^{195}$

To collect information and intelligence the MSU relied on regular patrols, covert observations and quick-impact projects that involved the exchange of material aid to the population for information. Carabinieri officers stressed their non-martial posture and their method of striking up conversations with citizens as major assets in collecting information, practising what they called a 'walk and talk' policy. ${ }^{196}$

As in Bosnia and Herzegovina, several factors undermined the effectiveness of the Carabinieri. Formal rules generally forbade the use of techniques such as wiretapping, infiltration and plain-clothes observation; ${ }^{197}$ after all, executive policing was primarily the responsibility of UNMIK Police. As a consequence, the Carabinieri were unable to apply their full civilian policing potential (another Italian institution contributing to fighting crime in Kosovo, the Guardia di Finanza, also faced numerous restrictions). Moreover, many commanders of regular forces did not understand the structure and task spectrum of the Carabinieri, which at times led to the inappropriate deployment of the MSU/Carabinieri and conflict between regular KFOR units and the Carabinieri. ${ }^{198}$

Furthermore, divisions of labour were unclear between the gendarmerie units of the MSU and their UNMIK equivalent, the special police units (SPUs). The job of the SPUs was to support regular UNMIK Police officers and KFOR in the field of public security (it took over a year for the SPUs, as for UNMIK as a whole, to deploy fully). The SPUs were reluctant to coordinate their activities with the $\mathrm{MSU}$, regarding it as competition and the KFOR command chain (KFOR had to approve UNMIK requests for support) as cumbersome. ${ }^{199}$ UNMIK also complained that the MSU did not properly share criminal intelligence and failed to inform UNMIK about operations. ${ }^{200}$ One of the problems of UNMIK Police was that 
the MSU, being part of KFOR, had access to superior equipment, such as helicopters that enabled its quick deployment. ${ }^{201}$

Tensions between the gendarmerie and military approaches persisted over the years. Over time it became more difficult to seize weapons or drugs. Nevertheless, the Carabinieri continued to stage raids in various parts of Kosovo, such as searches of family homes where illegal weapons were supposedly held. These raids often did not find the approval of regular KFOR commanders, who were concerned that public opinion in their respective area of responsibility might swing against KFOR. ${ }^{202}$ As in Bosnia and Herzegovina, use of versatile force by the Carabinieri in Kosovo did not go unchallenged.

\section{Afghanistan}

After 9/11 the US-led Operation Enduring Freedom (OEF) toppled the Taliban regime in Afghanistan which had hosted Al Qaeda. Subsequently, the OEF continued to conduct operations against suspect terrorists and insurgents. The mission operated in parallel to the International Security Assistance Force (ISAF), which was mandated by the UN Security Council and, in 2003, became NATO-led. After an initial period of deceptive calm that lasted until around 2004, insurgent attacks intensified, an increasing number of provinces became war zones once more and the ISAF mission turned into NATO's biggest war ever.

Numerous causes account for the ever-worsening security situation in Afghanistan. Decades of war had left political and ethnic divisions across Afghanistan and created economic havoc. Post-Taliban politics were dominated by power politics and corruption, with more and more citizens losing faith in the administration of President Hamid Karzai. Regional factors were also detrimental to stability, with neighbouring countries jockeying for influence in Afghanistan.

International mistakes weigh heavily, too. In contrast to the Balkans, international actors during the initial post-Taliban years sent few troops, even fewer police officers or judicial personnel and little economic aid to Afghanistan, especially to areas outside of Kabul. ${ }^{203}$ This 'light footprint strategy' reflected the belief that Afghans would not support a massive international presence, and the aversion of the Bush administration to nation-building as well as its fixation on Iraq. But Afghanistan was too weak 
to help itself. Other problems of involvement included international (especially US) support for Afghan warlords as well as for the Pakistani military regime, despite Pakistani support for the Taliban, and insufficient understanding of Afghanistan's political and social complexities.

Deficient donor coordination exacerbated these problems. Implementing the 'lead nation' concept developed for Afghanistan in early 2002, the US focused on defence reform, Germany on police reform, Italy on justice reform, the UK on counternarcotics and Japan on DDR. This concept created artificial boundaries between sectors and made progress in one sector the hostage of progress in another. The increasingly hegemonic position of the US in Afghanistan de facto abolished the concept. Yet international practices in Afghanistan remained disparate - including with regard to the use of force.

The difficulties and dilemmas of using force in post-war Bosnia and Herzegovina and Kosovo paled in significance compared to those in Afghanistan. In contrast to post-Dayton Bosnia and Herzegovina and Kosovo, this was a war, and one in which international actors had to do so many things at the same time: fight insurgents, terrorists and criminal groups, avoid civilian casualties, promote civilian policing under fire and constantly adapt their strategies to their formidable enemies. Concepts such as the Blue Box/Green Box idea that had guided police-military cooperation in the Balkans were of little use in Afghanistan; these concepts presumed a minimum linearity in security dynamics, yet tactics such as using child suicide bombers or improvised explosive devices (IEDs) defied any linearity - anything could happen anywhere at any time. Security forces therefore had to be able to apply force from the maximum to the minimum, and to switch between levels within seconds. Their ability and willingness to do so differed, reflecting differences in the institutions of sending states.

\section{The use of force by the United States}

The US relied primarily on maximum force in Afghanistan, benefiting from superior weaponry and technology. But this was an asymmetric war that compelled the US to apply force discriminately, as indiscriminate force was ineffective and even counterproductive, increasing civilian casualties and making local enemies. 
In late 2001 US-led OEF forces managed to rout their enemies within weeks. The US strategy was based on airstrikes, small numbers of US special forces soldiers and CIA operatives, and cooperation with the Northern Alliance and other anti-Taliban forces. The operation revealed both the advantages and the risks of relying on local allies: the US suffered few casualties, but key leaders, especially Osama Bin Laden, escaped to Pakistan. Following the toppling of the Taliban, the US continued to wage its 'war on terror', focusing on southern Afghanistan. Often special military forces would deploy in small units, identify targets and direct airstrikes towards them.

US troops made gains on the tactical level, but flawed strategic decisions rendered these gains unsustainable. The Bush administration moved military and intelligence assets from Afghanistan to Iraq, and tasked remaining forces to focus on Al Qaeda, even though ordinary Afghans were more concerned about crime, human rights violations and corruption, for which Afghan government officials and members of security forces were often responsible. Moreover, US military operations, especially airstrikes and night raids, caused civilian casualties, which the US struggled to avoid because intelligence was often faulty and terrorists and insurgents were indistinguishable from the general population. In addition, the US cooperated with warlords who seemed expedient in tracking down members of Al Qaeda and providing a modicum of stability. ${ }^{204}$ In combination, these problems led to a renaissance of the Taliban. Its ideology had always resonated with only a minority of Afghans, yet citizens saw the Taliban as preferable to brutal and corrupt officials and the warlords who had destroyed the country during the 1992-1996 civil war and whose unpopularity had brought the Taliban to power.

The US response to the worsening security situation was to step up force. Military and intelligence personnel would draw up lists of wanted individuals and then stage 'kill or capture' operations (capture in many cases leading to detention without trial). ${ }^{205}$ But there was no coherent approach for dealing with the growing violence engulfing Afghanistan. Only in 2009 , by which time the Taliban controlled large swathes of the country and even made incursions into formerly safe districts, did the US adopt a COIN strategy for Afghanistan. ${ }^{206}$ The adoption of this strategy by the Obama administration led to a massive increase in US funding and the deployment of an additional 30,000 US soldiers to Afghanistan. 
COIN placed a premium on the protection of the population, instead of the number of enemies killed. To rally public support behind international stabilisation efforts and the Afghan government, civilian casualties had to be avoided. US soldiers were ordered to switch quickly between roles: they had to kill insurgents, ${ }^{207}$ drink tea with villagers to foster trust and gather information about tribal dynamics or local crime problems, and patrol on foot to reassure the population, all the while watching out for suicide bombers and IEDs.

Implementing the strategy was tricky. Switching between roles in an unpredictable environment implied significant risks to troops, and was thus at odds with the Powell-Weinberger doctrine mentioned earlier. The COIN concept was based on the premise that security could only be improved by accepting a short-term increase in risk. As the number of US casualties grew, under the leadership of General Petraeus the US once again stepped up night raids and drone strikes. These tactics may have helped to reduce US losses, but caused numerous civilian casualties - discriminating between enemies and bystanders remained tricky. And operations did not translate into strategic success: Pakistan continued to send a seemingly unlimited number of fighters, and many Afghans accused their government of corruption and incompetence.

Counter-drug efforts also illustrate the US reliance on maximum, discriminate force. For many years US military commanders, and even special forces, were reluctant to participate in drug control in Afghanistan. ${ }^{208}$ But it became increasingly obvious that a nexus existed between drug traffickers and insurgents (although many government officials and members of the Afghan security forces profited from the drug industry, too). At the 2008 NATO summit in Budapest, upon the initiative of the US, members agreed to target this nexus. ${ }^{209}$ This decision was a catalyst for an increase in US operations against opium and heroin traffickers. Such operations forged close alliances between the US military and its federal law enforcement agencies. By summer 2011 the DEA had around 60 agents permanently stationed in Afghanistan who collected criminal intelligence and shared it with the military. The DEA also rotated paramilitary units to Afghanistan, which at times became involved in firefights. ${ }^{210}$

Support to the Afghan National Police (ANP) was another element of US war-fighting. ${ }^{211}$ The US had begun to support the ANP in 2003, when the State Department contracted DynCorp to train street-level police officers, 
filling a gap resulting from the German focus on ANP commanders. But many criticised DynCorp trainers as lacking adequate skills and planners for not including paramilitary skills in curricula. ${ }^{212}$

In 2005 the Pentagon pushed aside the State Department as the main promoter of police reform. The Pentagon funded its security assistance through the Combined Security Transition Command Afghanistan (CSTC-A). By 2010 international funding for the Afghan security forces was around \$1 billion per month. The bulk of the funding was destined for the Afghan National Army (ANA), although the ANP was given a sizeable $\$ 300$ million per month. ${ }^{213}$ CSTC-A provided around 90 per cent of the funding for the Afghan security forces, under the multinational umbrella of the NATO Training Mission - Afghanistan (NTM-A), which since 2010 has been the main institution responsible for supporting the Afghan security forces. Moreover, as sending states deployed only a few civilian police experts, US soldiers played a large role in training, partnering and mentoring Afghan police officers on the ground, as part of police operational mentor and liaison teams. In 2010, within the Afghan Ministry of Interior, almost all mentors were either active US military or retired officers working as contractors. ${ }^{214}$

The predominance of the Pentagon had a profound impact on the ANP, increasing numbers of officers trained, shortening training courses and moving the ANP towards paramilitarisation - this was security assistance focused on capacity-building, rather than sustainable SSR emphasising democratic accountability. Military skills were to help the ANP survive; yet casualty rates among ANP officers, who continued to be soft targets for insurgents, remained staggeringly high. ${ }^{215}$ The regular police (the Afghan uniformed civilian police) were taught primarily basic military skills during a mere six weeks of training. The US also used other elements of the ANP as a force multiplier for counterinsurgency: the Afghan Border Police, special units within the Afghan Counternarcotics Police and the gendarmerie-like Afghan National Civil Order Police (ANCOP).

Furthermore, the US supported militia programmes, despite much resistance from European partners, human rights organisations and many Afghans, who were concerned that militias would violate human rights, spread corruption and, after the departure of international troops, work for anyone willing to pay them. After 2009 the main programme was the Afghan Local Police (ALP), which the US wanted to grow to 30,000 by the 
end of 2013. The ALP consisted of lightly armed units protecting their villages. They were trained, mentored and often paid by US Green Berets (and sometimes also British Royal Marines). ${ }^{216}$ ISAF commander General Petraeus compared these militias to a neighbourhood watch with an AK47. ${ }^{217}$

While the US geared the ANP towards a COIN role, too little was done about civilian policing, despite its role in building rapport with the population and gathering criminal evidence and intelligence. In 2008 an Afghan Ministry of Interior official was quoted as saying: 'When I say I need weapons they bring thousands, when we ask for equipment for the CID they don't know [what to do]. ${ }^{, 218}$ In mid-2011 only 13 Afghan CID officers worked in Kandahar; in the 1980s, under President Najibullah, there had been $196 .{ }^{219}$ The deployment of US federal police agents tilted the balance away from war-fighting towards intelligence-led policing only so far; ${ }^{220}$ after all, foreign police needed local counterparts who spoke the languages and understood the local networks.

The adoption of the COIN strategy did not end the practice whereby the US (and other sending states) continued to use force selectively, depending on perceived political expediency (as in the Balkans). Those attacking NATO obviously became targets. Others, even if involved in serious crime, had little to fear, as they were regarded as vital for ensuring local stability, force protection or the safety of NATO supplies.

\section{The use of force by the United Kingdom}

If the US invested few resources in Afghanistan in the aftermath of the fall of the Taliban, this is even more the case with the UK. The UK deployed the second-largest number of troops to Afghanistan after the US, concentrating them in dangerous Helmand province. Some of the British Army missions seemed impossible, such as pushing the Taliban out of large areas with only a few men operating jointly with largely untrained Afghan soldiers and police officers. ${ }^{221}$

British troops - as in Kosovo - tried to be close to the population, such as by patrolling in small groups without full body armour and ready weapons. ${ }^{222}$ But when facing insurgent attacks, British soldiers used maximum force. In addition to regular troops, the UK deployed special forces to Afghanistan. Similar to US special forces, and in contrast to 
German forces (see below), British special forces engaged in the targeted killing of presumed enemies. ${ }^{223}$

The UK was also a keen ally of the US in attacking the insurgencydrugs link, ${ }^{224}$ which was particularly strong in Helmand. In these operations, lethal force was as much an option as arrest. Initially the UK, in its capacity as counter-drug policy lead nation, had focused on the manual eradication of opium poppy fields. But this practice drove many Afghan farmers who depended on opium cultivation into the arms of the Taliban. Around 2008, under US pressure, international counternarcotics actors, including the UK, shifted the focus to the higher echelons of the drug industry. This focus implied maximum, discriminate force (although questions remained over who could rightfully be targeted).

A crucial part of the UK's counterinsurgency campaign was to support Afghan security forces. The primary recipient of British support was the Afghan National Army; thus the SAS trained special counterterrorism units of the ANA. ${ }^{225}$ The UK also provided equipment, training and intelligence to the ANP. For counternarcotics operations, the UK supported special units of the ANP (the so-called 333 and 444 units). This included officers of SOCA mentoring Afghan officers and using techniques such as telephone intercepts, and British special military forces participating in search-anddestroy missions. ${ }^{226}$ Afghan special police forces used maximum force numerous times.

With regard to the regular Afghan police, British officials stressed that they had to be able to switch from a robust gendarmerie-type role to a community police role. ${ }^{227}$ In its areas of command, the British military geared the regular ANP towards versatility. At the same time, British police at headquarters level in Kabul pushed towards a civilian outlook of the ANP. For instance, British police officers within CSTC-A/NTM-A were a major driving force behind a police strategy adopted by the Afghan government in 2010 that, for the first time, delineated paramilitary and civilian tasks of the different ANP elements. ${ }^{228}$ Within the European Police mission (EUPOL), British police officers, like their colleagues from other countries participating in the mission, concentrated their efforts on improving civilian policing structures such as the CID pillar of the ANP. 
Afghanistan fundamentally challenged Germany's security concepts and practices. In the Balkans, Germany had struggled with using force; in Afghanistan, dilemmas were even starker.

During the initial post-Taliban years these dilemmas were manageable, because the security situation in Kabul and northern Afghanistan, where almost all German soldiers operated, was benign (in the sense that the warlords ruling post-Taliban Afghanistan cooperated with sending states instead of fighting them). The German army, in cooperation with German diplomats and development experts, was therefore able to concentrate its efforts on civilian reconstruction, development and humanitarian aid, primarily through provincial reconstruction teams (PRTs). To reduce risk, the Bundeswehr emphasised force protection, patrolling in large groups and displaying heavy weapons. ${ }^{229}$ By showing their readiness to use maximum force, German soldiers tried to avoid having to use force a practice reminiscent of the Cold War.

Reservations about the use of force marked all German actors, not only regular military units. The German intelligence agency provided tipoffs, but did not have the capacity or mandate to use force, often leaving the job to the US military. ${ }^{230}$ With regard to special military forces, a small number of German KSK soldiers were deployed to southern Afghanistan as part of the OEF's Operation Anaconda in spring 2001, looking for weapons caches, conducting surveillance and participating in combat. But the German approach was different from the US approach. During one surveillance operation a shepherd accidentally spotted KSK soldiers, who consequently had to abort the operation; when the Germans returned to camp, the US commanding officer scolded them for not killing the shepherd. Also, during joint German-US operations the Germans would leave the arrest of suspects to their US comrades. ${ }^{231}$ Such reservations reflected different rules of engagement and definitions of military necessity.

To reassure their public, German politicians used the term 'stabilisation mission' to describe the German role in Afghanistan. But this framing increasingly neglected the reality of war. The renascent Taliban were concentrated in Afghanistan's south and east, but to attack NATO supply lines and avoid the brunt of US and British military might in the 
south, the Taliban spread into the area of ISAF's Regional Command North, which was under German command. German troops on the ground found themselves hamstrung by bureaucracy and the requirement to use force only in self-defence - even preemptive engagement was initially banned. Soldiers who did use force became the subject of criminal investigation back home in Germany ('one foot in the grave and the other in prison', German soldiers would say).

German troops improvised within the narrow rules imposed on them. Many knew that tactics such as reducing the number of patrols increased mid- to long-term risks, by allowing insurgents and criminals to intimidate the population and prepare attacks. Indeed, the security situation in the north deteriorated, German casualties mounted, and German troops for the first time since the Second World War participated in large-scale ground operations under fire. Rules were now changed to allow greater use of force (what did not change was the fact that two-thirds of the German public wanted an end to the mission in Afghanistan). ${ }^{232}$

A watershed event in September 2009 gave the final push for policy change: the German commander of the PRT in Kunduz requested airstrikes against two fuel tankers captured by the Taliban, which resulted in many civilian deaths. ${ }^{233}$ German troops were now given weapons such as longrange artillery, and German politicians acknowledged that Germany was fighting a non-international armed conflict in Afghanistan. As IHL was now the guiding legal framework, the use of force became more palatable than under the criminal law paradigm that had hitherto governed the German engagement in Afghanistan.

The problem was, of course, that the Taliban and other armed opposition groups adapted to the stronger German posture. A German officer lamented: 'Now we have the heavy weapons we wanted and now we would be able to fight, but now the others do not want to fight anymore. ${ }^{234}$ Instead of challenging German troops in battle, insurgents used IEDs and suicide bombers. German troops found it ever more difficult to leave camp, and had to rely on US assets such as combat helicopters. Even as the war intensified and after restrictions had been relaxed, German rules governing the use of force remained relatively restrictive. Special forces, for example, would focus on the arrest of persons, while US soldiers frequently killed them. ${ }^{235}$ German politicians and military leadership also did not involve the Bundeswehr in drug control. ${ }^{236}$ Thousands of US troops 
were nominally under German command, but in fact operated according to their own, lethal, rules. Many German military officers criticised German caveats. One said: 'The two greatest threats stemming from Afghanistan for Germany's security are terrorism and drug trafficking. We are not allowed to use force against either of these. ${ }^{237}$

German idiosyncrasies also came to the fore in the field of police reform. Since 2002, when Germany became the lead nation for police reform, the focus had been on civilian policing. In contrast to the three other sending states discussed in this paper, German police officers did not want to nudge the ANP towards a counterinsurgency role. This was the case with German officers working for the bilateral German Police Project Team (GPPT) as well as those working for EUPOL. ${ }^{238}$

That Germany paid heed to its domestic institution of separating police and military roles showed in different ways. ${ }^{239}$ First, Germany supported primarily the regular uniformed police and criminal police at police training centres, as well as police officer and non-commissioned officer candidates at the Afghan National Police Academy. It stayed away from ANCOP (which German police officers were generally not allowed to train) and counternarcotics and counter-drug units, as well as US-supported militias. Second, Germany tried to convince their NATO partners to train the ANP for longer periods of time, and to emphasise civilian policing skills (including literacy). Third, the GPPT was not placed under the command of NTM-A. Fourth, German ministry officials made sure there was no overlap in the work of the military police (Feldjäger) and German civilian police officers. ${ }^{240}$ Fifth, Germany did not participate in embedded partnering with the ANP, as this would have increased risks for German police officers (who were compelled, among other security measures, to spend the night inside their camps). Sixth, Germany focused on relatively safe areas, defying US pressure to become involved in so-called key terrain districts. These districts were centres of population and vital infrastructure, and were generally the most dangerous ones in Afghanistan.

In trying to promote minimum police force in Afghanistan, Germany faced numerous obstacles. These included worsening security conditions, a lack of interest in civilian policing within the Afghan Ministry of Interior (which was dominated by former fighters whose outlook was military) and other priorities and practices of Germany's NATO partners. 
Some problems were homemade, however. Most gravely, Germany invested relatively small means into civilian policing reform, especially during the early post-Taliban period. Even after 2010, when Berlin decided to increase police aid to around $€ 50$ million per year, German investments in the ANP paled in comparison to funding from the Pentagon (the EUPOL mission suffered even more from relative insignificance). Also, in contrast to the number of military trainers from other sending states, the number of German police trainers was low; only in 2010 did Germany agree to significant increases, yet even then the maximum number of GPPT personnel was 200. Recruitment had been a problem ever since Germany became involved in Afghanistan. The federal government had to rely on volunteers, but the Länder governments and police unions proved reluctant to deploy Länder police officers, as they were needed at home and the risks in going to Afghanistan were deemed high.

\section{The use of force by Italy}

Like the three other sending countries, Italy applied all levels of force in Afghanistan. Italy contributed the fourth-largest contingent to ISAF, after the US, the UK and Germany. It deployed most of its troops to the western province of Herat, setting up a PRT (in 2005) and assuming the command of ISAF's Regional Command West. Similar to Afghanistan's north, the western region was relatively peaceful following the fall of the Taliban regime. Many Afghans and international observers credited warlord and governor Ismail Khan for this benign security situation.

As Afghanistan descended back into war, so did the west of the country. Italy deployed elite combat forces, including special forces that partnered with US and British special forces. But Italy's allies, particularly the US, were critical of caveats that did not allow the deployment of Italian soldiers to violent southern Afghanistan or their use in front-line combat (in 2008 some caveats were relaxed). ${ }^{241}$ Media reports even claimed that Italy was paying the Taliban in order to buy peace and reduce Italian casualties. $^{242}$

Italy's police forces once again added a special note of versatility to international intervention. ${ }^{243}$ Carabinieri tasks included protecting former King Zahir Shah in 2002, training the ANP as part of the OEF mission and supporting troops from Italy and other countries in Herat. The Guardia di 
Finanza cooperated with CSTC-A in training the Afghan Border Police and customs officers in Herat. The Carabinieri and Guardia di Finanza seemed good fits for a country where insurgency, crime and official corruption were often indistinguishable, with people, drugs and weapons smuggled across the border between Iran and Afghanistan.

The Carabinieri's main function in Afghanistan was to support the ANP, more precisely ANCOP. The members of this relatively small force were recruited and deployed across the country, and regarded as not only more robust but also more competent than regular uniformed police officers, and less corrupt. ${ }^{244}$ This qualitative edge stemmed from the fact that ANCOP received 16 weeks of training (in contrast to the regular police, who were trained for a mere six to eight weeks), and was relatively well equipped. ANCOP over the years became a key pillar of counterinsurgency. The force was used for replacing police units undergoing training as part of the Focused District Development programme, and for holding areas taken back from insurgents.

The Carabinieri supported ANCOP primarily by teaching skills such as the handling of weapons (including machine guns) and IED awareness. Not all skills taught by the Carabinieri were of a paramilitary nature; for example, Carabinieri instructors had one week to teach basic computer skills to ANP officers, most of whom had never used a computer before. ${ }^{245}$ But the emphasis was on versatile force. The leadership of ISAF and NTM-A lauded the work of the Carabinieri, saying that they filled an important gap in the training of the ANP. ${ }^{246}$ The Carabinieri, in turn, appreciated working within a militarised environment, and were critical of DynCorp's civilian police trainers alongside whom they had to work. One Carabinieri officer, complaining that DynCorp did not teach ANCOP skills such as shooting with body armour and CRC, said: 'We are soldiers, not civilian police officers turned contractors. They should not be in a war zone. ${ }^{247}$

The Carabinieri were popular among most international actors, but Italy's role in Afghanistan should not be overestimated. Although by summer 2010 around 130 Carabinieri were working in Afghanistan, ${ }^{248}$ the demand for gendarmerie expertise was much higher. Guardia di Finanza officers, whose skills for investigating business crime and corruption were also in high demand, were even scarcer. When EUPOL requested officers from that agency, it took two months for Italy to respond, and even then the government sent only four officers. ${ }^{249}$ 


\section{CONCLUSIONS}

This concluding section summarises the key findings, discusses lessons to be learned for future interventions and proposes paths for further study.

\section{Key findings}

Liberal democracies are under pressure to use versatile force in war-torn countries. The reasons for this are varied: the need to cope with diverse forms of violence and win the hearts and minds of local citizens; public demands to prevent and punish human rights violations; changing views of sovereignty and international intervention; international law; and the presence of international organisations. Putting into effect demands for versatile force has profound implications for both military and police forces: the military must be able to move towards minimum force and the police towards maximum force.

All liberal democracies face these constraints, and yet they use force and restructure their security forces differently. Section 3 shows that the US and Germany have had greater difficulties in calibrating levels of force to the problem at hand than the UK and Italy. These findings corroborate the main argument of this paper - the domestic institutions of intervening states mediate between demands for versatile force and security practices.

In Bosnia and Herzegovina the US relied on show of force and interpreted the Dayton mandate narrowly. As a consequence, it had difficulties coping with paramilitary police, suspected war criminals and 
rioters. In post-war Kosovo, too, US efforts to calibrate the use of force were improvised and sporadic. After $9 / 11$ the US faced a situation in Afghanistan where terrorism, insurgency, crime and corruption were inextricably intertwined. The adoption of the COIN doctrine in 2009 put a premium on the discriminate and proportionate use of force. Yet, as US casualties soared, the US again showed a propensity for maximum force, both by its own troops and by Afghan security forces receiving US support. The traumatic experiences in Vietnam and Somalia left deep imprints, particularly on the Pentagon, with risk aversion leading to the prioritisation of force protection.

The UK stood ready to employ maximum force in Bosnia and Herzegovina. But in comparison to the US, the UK was better prepared for efforts against suspect criminals. The British performance in Kosovo was similar to that in Bosnia and Herzegovina. British forces were ready to counter a Yugoslav military attack, yet were able to calibrate levels of force to the problem at hand. In Afghanistan the UK applied maximum force, but at the same time tried to put into effect the COIN precept of working closely with the population. In all three cases, the British Army proved able to scale up or down levels of force. British police officers were generally wedded to minimum force. However, like their US colleagues, in Afghanistan they supported robust host-state police forces. In all three interventions the British approach reflected previous experiences with force, from colonial times to the Troubles in Northern Ireland, as well as domestic military support to civil authorities.

In the Balkans, Germany relied on heavy force protection and show of force. It therefore struggled with opponents such as rioters, although the performance of regular troops changed over time. Special forces more readily embraced the notion of versatile force; German operations against suspected war criminals marked a sea change in German security policy. In Afghanistan, Germany was once more highly casualty averse. Even after its politicians had acknowledged that this was war, Germany remained a reluctant ally within NATO, imposing numerous caveats on its security personnel. Problems of versatility are apparent not only in the case of the military but also the police, where Germany held on to the vision of civilian policing. German difficulties with versatile force resulted from domestic formal and informal rules that led to casualty aversion and put a wedge between the military and the police. 
Italy is the only country discussed in this paper that commands gendarmerie forces. In both Bosnia and Herzegovina and Kosovo it deployed combat forces, but the most outstanding Italian contribution was the deployment of the Carabinieri. Initially, the Carabinieri were hamstrung by the failure of commanders of regular military forces to understand gendarmeries. The situation improved over time, and the Carabinieri became crucial for putting pressure on rioters, suspected war criminals and members of organised crime groups. In Afghanistan, Italy again drew on the Carabinieri, one of whose main tasks was to train Afghan gendarmerie forces. There is little systematic evidence that the Italian military has a competitive edge in using versatile force abroad, despite its significant domestic role in crime-fighting. In contrast, the Carabinieri have keenly exported the gendarmerie model, both in an executive capacity and by supporting host-state police forces.

The analysis thus reveals differences in the way states use force. It also reveals a shift towards versatile force between 1996 and 2011. The security gaps in the Balkans and post-9/11 counterterrorism and counterinsurgency have led to some institutional learning. For example, CRC is now an essential element of pre-deployment training - in contrast to the mid-1990s, Western militaries are no longer limited to either shouting or shooting.

However, institutional learning occurs primarily on the tactical and operational levels, as resilient domestic institutions stand in the way of fundamental policy transformation on the strategic and political levels. This resilience finds expression, among other ways, in power struggles within security forces. As part of state efforts to adapt force structures to asymmetric security risks, special military forces and special and robust police forces have seen much growth. But these forces' cultures do not match the cultures of regular security troops. In the US, the regular army limited the influence of the US Marine Corps and special forces during the Vietnam War. ${ }^{250}$ Forty years later, special forces again complained about being put on a short leash by a risk-averse, bureaucratic Pentagon. ${ }^{251}$ Special forces have much in common and cooperate intensively across borders. But they are the tools of political, military and police superiors, and these superiors' strategies reflect idiosyncratic domestic formal and informal rules governing the use of force. 
The analysis also showed that size matters. Germany has been an active proponent of civilian police reform in Afghanistan; but it committed relatively few personnel and small funding, allowing the Pentagon to tilt the balance towards paramilitarised policing. With regard to the Italian Carabinieri, their numbers were too small to fill the security gaps in the Balkans and Afghanistan.

Last, states use force selectively. For example, the US has come under criticism for not arresting suspected war criminals in Bosnia and Herzegovina, and for cooperating with KLA members and Afghan warlords. Stories of well-meaning international actors struggling with local strongmen are oversimplified. Even in stable countries, politicians and security forces face dilemmas. How much should security forces rely on informers? Should arrests be made at an early stage, at the risk of allowing ringleaders to escape? Should the police focus on burglars, even though this might drive up the unsolved murder rate? International intervention exacerbates such dilemmas.

\section{Lessons to be learned}

These findings suggest lessons for future intervention. One lesson is that international actors should take into account discrepancies in the use of force when designing and implementing international intervention. Certainly the security practices of states have seen much harmonisation. States have adopted the military models of major powers, which explains why military forces are structured along similar lines. ${ }^{252}$ Also, pressure to calibrate the use of force has led to a harmonisation of intervention practices. Democracies must defend human rights. This means that the objectives of interventions, ranging from the stabilisation of war-torn countries to counterterrorism, do not justify all means.

But important differences remain, some of which this paper describes. Military forces may resemble one another more and more, yet political priorities, casualty aversion, the means chosen to intervene in a war-torn country and the kind of support extended to host-state security forces will continue to diverge. Also, discrepancies in the structure of police forces continue to outweigh trends towards harmonisation. These differences will not go away. After all, the domestic institutions that are the main source of such practices are resilient to change. The concept of path 
dependency suggests that previous decisions limit the set of new decisions. Critical junctures such 9/11 contribute to policy harmonisation, yet do not override different historical experiences.

Another lesson is the need for versatile force: states must be able to cover the entire continuum of force while calibrating levels to the problem at hand. Public pressure, changing conceptions of sovereignty and peacekeeping, international law and international organisations all invite versatile force. The situation on the ground weighs heavily, too; no one level of force alone is sufficient for stabilising war-torn countries.

Maximum force may be necessary to manage or deter acts of highend violence such as attacks by militarily organised enemies. But a fixation on maximum force may lead to force being applied disproportionately and ineffectively. It may also lead decision-makers to use a narrow definition of military priorities that leads to the labelling of problems such as looting as civilian issues. Intermediate force allows security forces to avoid disproportionate or insufficient force against opponents, but it may be insufficient against high-end violence and exaggerated against low-end violence. Minimum force, in liberal democracies, is the choice level against problems involving individual and low-grade violence. Minimum force even holds advantages against insurgents, terrorists or gangs, by reducing the risk of 'collateral damage' that would harm the perceived legitimacy of security forces. The downside is that it is easy to overpower security forces relying exclusively on minimum force.

How can states intervening in war-torn countries employ versatile force? One option is that the same sending state deploys security forces each of which specialises in one level of force. The problem is that many democracies lack intermediate force options such as gendarmeries. Also, this approach presupposes linearity in security dynamics, with one force stepping in when another can no longer cope or is no longer needed. Yet often dynamics are not linear, and security forces must switch between levels of force within seconds.

A second option is to establish divisions of labour between intervening states, with each specialising in specific levels of force. Here the problems are the timely deployment of security forces to another site; states' unease in depending on other states; and the coordination problems that would inevitably arise. 
A third option is to enhance the versatility of all security forces sent to a war-torn country. Ideally, the same person can be a community police officer and a war-fighter, and seamlessly switch between these roles. But the political and practical challenges are enormous, and so are the cultural and psychological challenges; inculcating both a civilian police and a warrior spirit in security forces is tantamount to creating split personalities.

Given the limitations of each of these three options, states should combine them. Deploying specialised forces remains necessary, as these forces have unique competitive advantages. States should also help each other out, and not regard their area of responsibility as their fiefdom. To know what support to request, extend and expect, civilian and military decision-makers must better understand their partners' security sectors.

Most importantly, states should invest in versatile security forces. This is particularly important for the military, which is the main security provider in peace operations. Calibrating levels of force should be a central element of pre-deployment training and actual operations, as well as of military transformation more generally. Many governments and militaries prefer to rely on maximum force. Telling soldiers to take higher short-term risks in order to win the trust of the population and improve security conditions is a hard sell for civilian leaders and military commanders. However, the insurgencies in Iraq and Afghanistan, which were exacerbated by 'collateral damage', underline the costs of not investing in versatility.

To be sure, the timely deployment of capable civilian police officers to war-torn countries should be a top policy priority. Due to their characteristics, civilian police run a lower risk of applying disproportionate force than is the case with paramilitary or military forces. Also, securing the chain of evidence and taking insurgents, terrorists, traffickers or rioters to court has significant advantages over treating them as enemies of war or not even affording them basic rights of international law. Treating terrorists, for example, as criminals and not as enemies of war (or unlawful combatants) deprives them of legitimacy (assuming fair judicial procedures) and propaganda opportunities.

But states are reluctant to deploy civilian police into high-risk zones. Military battles, terrorist attacks, criminal violence and riots may all occur in the same space, at the same time. The means of civilian police are quickly exhausted when facing higher-end violence. Moreover, civilian police officers usually cannot be ordered to work abroad, are not given sufficient 
incentive to participate in a foreign mission and are needed at home. For these reasons, investing in military transition skills will be crucial.

Using force in war-torn countries is difficult because it involves tradeoffs and compromises. Two positions on the use of force can be distinguished. Representatives of the first position stress that security comes first. ${ }^{253}$ Establishing security in volatile environments inevitably undermines a strict division of labour between the military and the police, and may also clash with accountability as commonly understood in liberal democracies. After all, the population in war-torn countries seek security, first and foremost, and may therefore support even brutal and corrupt security forces, ${ }^{254}$ as long as brutality and corruption do not exceed a level where the costs to the population outweigh the gains of increased security. ${ }^{255}$ International actors may tout minimum force as the perfect default option, but local citizens worry that minimum force may be insufficient against predatory groups using high levels of violence. ${ }^{256}$

Those embracing this security-first approach place emphasis on versatile security forces. They also oppose the view that versatility implies high risks of disproportionate force and less democratic control. What matters are control mechanisms, rules and compliance with those rules. Indeed, a strong emphasis on hierarchy and discipline may be conducive to control. In some Mediterranean countries, fewer complaints of misconduct are lodged against gendarmerie forces than against regular police forces. ${ }^{257}$ Those advocating security first would also plead for a military role in police training. In war-torn countries, particularly in high-risk zones and outside major cities, civilian police tend to be absent. As a former US military officer writes, 'military advisors must therefore become involved in assessing and mentoring police forces early on, training them in critical stability police tasks, but guiding and mentoring them to ultimately become a communitybased police force responsive to their citizens' ${ }^{258}$ From this perspective, support by international military forces for local police forces is preferable to not supporting local police at all.

In contrast, representatives of the second position emphasise minimum force and democratic governance. David Bayley lists four principles of democratic policing: police should be responsive to local communities, accountable to the rule of law, focused on the defence of human rights and act in a transparent manner. ${ }^{259}$ All too often, international actors have not adhered to these principles. For instance, 
much of US foreign police support has focused on capacity-building instead of democratic governance. ${ }^{260}$ Yet effectiveness and legitimacy are two sides of the same coin; moreover, the protection of people from disproportionate force is a democratic requirement in itself. International actors, in their efforts to improve state responses to violence, should therefore pay equal attention to democratic control, and give priority to minimum force.

Theoretically, versatile security forces perfectly scale the use of force to the problem at hand, avoiding disproportionate force. However, advocates of this second position worry that in practice versatility will lead to the use of disproportionate force. ${ }^{261}$ Also, versatile security forces have militarised characteristics that include a strong sense of hierarchy, secrecy and elitism, which may hamper democratic oversight. Moreover, the blurring of military and police roles may lead to situations where it is unclear who is responsible for overseeing which security forces, and where security forces can blame each other for failures of intervention.

Both positions are valid. States intervening in war-torn countries should try to do both: help establish security while at the same time safeguarding the principles of minimum force and democratic accountability. Whether intervening states must compromise between these principles, and how they best go about in finding the right balance, depends on a variety of factors, including international mandates, the actors intervening in a war-torn country and conditions on the ground. While there are no blueprints for the use of force in such countries, intervening states should avoid exaggerated and insufficient force, and work towards strong and accountable security forces.

\section{Critical knowledge gaps}

Different positions on the use of force and the fact that each international intervention is unique pose challenges to the formulation of concrete policy recommendations. Moreover, to be able to formulate firmer recommendations beyond the general guidance outlined above, knowledge gaps must be filled. Any move towards versatile force, such as by creating and deploying more gendarmerie forces, should be based on sound evidence. Authors wanting to fill knowledge gaps could focus on various aspects. 
One option is to expand the comparative framework of this paper by including cases of intervention by states other than Western liberal democracies. One would assume that divergence of intervention practices is even more obvious when looking at non-Western states. If the domestic institutions of Western liberal democracies governing their use of force differ, the domestic institutions of other states are likely to differ even more. For example, in many weak democracies and autocracies the military has a prominent domestic role, ${ }^{262}$ and security actors such as militias, palace guards or fire brigades complement or substitute for regular military and police forces. Empirical research should reveal the scope, forms, causes and consequences of the use of force in different environments. This requires better gauging the experience of non-Western researchers (who may not speak or publish in English).

Importantly, a broader comparative analysis should include intervention by UN Blue Helmets and troops of non-Western regional organisations. Policy divergence may affect such missions even more than NATO and EU missions, where the main member states are Western liberal democracies. Cases worth studying include efforts against gangs and rioters by contributors to the UN Stabilization Mission in Haiti; practices against the smuggling of conflict goods by contributors to the UN missions in the Democratic Republic of the Congo; the performance of international military, gendarmerie and police forces against militias and crime groups during UN operations in Timor Leste; and the use of force by Nigerian troops in Sierra Leone as part of an intervention by the Economic Community of West African States Monitoring Group in the late 1990s. Such studies should shed light on, among other aspects, the specificity of mandates, doctrines, rules of engagement and the actual use of force. Such research would help to test this paper's claim that the domestic institutions of intervening states, not the international organisation leading an intervention, are the primary drivers behind the use of force.

Studies could also examine the performance of security forces. Too often, verdicts on the performance of security forces are based on anecdotal evidence. For example, authors applaud the performance of gendarmeries in war-torn countries, despite the lack of empirical evidence. ${ }^{263}$ Research could compare the conduct of different security forces within and across countries. This kind of comparative work would elucidate the pros and cons of different mechanisms for controlling security 
forces, whether international or domestic. Control mechanisms may be internal or external, exclusive or inclusive and statutory or non-statutory. Which control mechanisms are the most appropriate depends on security conditions, the structure of the respective security sector and legal frameworks.

Change is a long-term, arduous process, with success likely to be no more than partial. A precondition for any successful reform is to understand the formal and informal institutions of host states, particularly the interests of security forces. What security forces (both international and domestic) want depends on their nationality, security situation and type of force. Also, members of the same security force may hold different views, depending on rank, function, previous experience and status (such as active duty or reserve). This paper has emphasised differences between states, oversimplifying a more complex picture. More works are needed that systematically compare the features of security forces within and across countries.

Security and development gains can only be realised through striking a balance between international intervention and national traditions. International actors wanting to change the characteristics of host-state security forces must understand their clients. But it is at least as important that they understand themselves. Perhaps the most revealing insight flowing from this paper is that challenges in achieving versatility point to the requirement for security sector reforms not just in states emerging from conflict but in those intervening states that seek to support them. 


\section{NOTES}

1 Drafts of this paper were presented at a workshop organised by the Geneva Centre for the Democratic Control of Armed Forces (DCAF) on 26 May 2011; at the 11th Biannual Conference of the European Research Group on Military and Society in Amsterdam on 14 June 2011; at seminars at the Goethe University Frankfurt on 4 July 2011 and 6 February 2012; and at the Department of Peace Studies, National Centre for Police Research, Kabul University on 10 July 2011. For comments and suggestions I am grateful to the participants. I also thank DCAF for supporting this publication project. Thanks are due to the representatives of governments, security forces, international organisations and non-governmental organisations in Bosnia and Herzegovina, Kosovo and Afghanistan who shared their insight with me. I am particularly grateful to the German Ministry of Interior and the German Police Project Team in Kabul and Mazar-e Sharif for their support. Others who have provided ideas, feedback, information and support include Janusz Biene, Max Bornefeld-Ettmann, Benjamin S. Buckland, Christopher Daase, Marleen Easton, Stefan Engert, Zsófia Hargitai, Julian Junk, Jörg Krempel, Marc Krupanski, David M. Last, Derek Lutterbeck, Dennis Michels, Christian Millotat, Thomas Müller, Niklas Schörnig and Ursula C. Schröder. Special thanks go to Alice Hills, Alan Bryden, Heiner Hänggi, Albrecht Schnabel and an anonymous reviewer, who have provided constructive and insightful comments on previous drafts of this paper, and to Cherry Ekins for copyediting the text. Any remaining errors and shortcomings are my responsibility.

2 For critical views on militarised foreign policing see Alice Hills, 'International Peace Support Operations and CIVPOL: Should There Be a Permanent Global Gendarmerie?', International Peacekeeping 5(3), 1998, pp. 26-41; Alice Hills, 'The Inherent Limits of Military Forces in Policing Peace Operations', International Peacekeeping 8(3), 2001, pp. 79-98; Cornelius Friesendorf, 'Paramilitarization and Security Sector Reform: The Afghan National Police', International Peacekeeping 18(1), 2011, pp. 79-95.

On these dimensions see John Casey, Policing the World: The Practice of International and Transnational Policing (Durham, NC: Carolina Academic Press, 2010), pp. 7-14.

4 One could question the distinction between political violence and riots, and regard the latter as an expression of the former. But this paper treats riots separately from terrorism and insurgency because riots tend to be less lethal and more spontaneous, and subsuming riots under the same category as terrorism and insurgency might be construed as implying that the same counter-strategies should be applied.

5 David H. Bayley, Patterns of Policing: A Comparative International Analysis (New Brunswick, NJ: Rutgers University Press, 1990), pp. 21-100.

6 Some scholars acknowledge that policing can encompass the activities of actors other than the police: Robert Reiner, The Politics of the Police (Oxford: Oxford University Press, 2000), pp. 3-4.

7 Robert J. Art and Kenneth N. Waltz (eds), The Use of Force: Military Power and International Politics (Lanham, MD: Rowman \& Littlefield, 2009). 
On minimum force in counterinsurgency see the classic study of Sir Robert Grainger Ker Thompson, Defeating Communist Insurgency: Experiences in Malaya and Vietnam (London: Chatto \& Windus, 1966); on minimum force requirements in the nuclear age see Morris Janowitz, The Professional Soldier: A Social and Political Portrait (Glencoe, IL: Free Press, 1960).

9 See, among many others, Ethan A. Nadelmann, Cops Across Borders: The Internationalization of U.S. Criminal Law Enforcement (University Park, PA: Pennsylvania State University Press, 1993); Bethan K. Greener, The New International Policing (Basingstoke: Palgrave, 2009).

10 María José Moyano Rasmussen, 'The Military Role in Internal Defense and Security: Some Problems', Occasional Paper No. 6, Center for Civil-Military Relations, Naval Postgraduate School, Monterey, CA (1999); Karl W. Haltiner, 'Policemen or Soldiers? Organisational Dilemmas of Armed Forces in Peace Support Operations', in Gerhard Kümmel (ed.), The Challenging Continuity of Change and the Military: Female Soldiers, Conflict Resolution, South Africa (Strausberg: Sozialwissenschaftliches Institut der Bundeswehr, 2001), pp. 359-384.

Derek Lutterbeck, 'Between Police and Military: The New Security Agenda and the Rise of Gendarmeries', Cooperation and Conflict 39(1), 2004, pp. 45-68.

Peter B. Kraska, 'Militarization and Policing - Its Relevance to 21st Century Police', Policing 1(4), 2007, pp. 501-513.

Christopher Andrew, Richard J. Aldrich and Wesley K. Wark (eds), Secret Intelligence: A Reader (London: Routledge, 2009).

Steve Coll, Ghost Wars: The Secret History of the CIA, Afghanistan, and bin Laden, from the Soviet Invasion to September 10, 2001 (London: Penguin Books, 2004).

Peter Andreas and Richard Price, 'From War Fighting to Crime Fighting: Transforming the American National Security State', International Studies Review 3(3), 2001, pp. 31-52; Kraska, note 12; Donald J. Campbell and Kathleen M. Campbell, 'Soldiers as Police Officers/Police Officers as Soldiers: Role Evolution and Revolution in the United States', Armed Forces \& Society 36(2), 2010, pp. 327-350.

Geoffrey B. Demarest, 'The Overlap of Military and Police Responsibilities in Latin America', Low Intensity Conflict and Law Enforcement 4(2), 1995, pp. 237-253; Derek Lutterbeck, 'Blurring the Dividing Line: The Convergence of Internal and External Security in Western Europe', European Security 14(2), 2005, pp. 231-253; Doron Zimmermann, 'Between Minimum Force and Maximum Violence: Combating Political Violence Movements with Third-Force Options', Connections 4(1), 2005, pp. 43-60. Alice Hills, 'Security Sector Reform and Some Comparative Issues in the Police-Military Interface', Contemporary Security Policy 21(3), 2000, pp. 1-26. See, for example, S. Colin Gray, Modern Strategy (Oxford: Oxford University Press, 1999). See also the vast literature on counterinsurgency and counterterrorism. Stephen M. Saideman and David P. Auerswald, 'Comparing Caveats: Understanding the Sources of National Restrictions upon NATO's Mission in Afghanistan', International Studies Quarterly 56(1), 2012, pp. 67-84; Pascal Vennesson, Fabian Breuer, Chiara de Franco and Ursula C. Schroeder, 'Is There a European Way of War? Role Conceptions, 
Organizational Frames, and the Utility of Force', Armed Forces \& Society 35(4), 2009, pp. 628-645; Christoph O. Meyer, 'International Terrorism as a Force of Homogenisation? A Constructivist Approach to Understanding Cross-National Threat Perceptions and Responses', Cambridge Review of International Affairs 22(4), 2009, pp. 647-666. Mary Kaldor, New and Old Wars: Organized Violence in a Global Era, With an Afterword, January 2001 (reprinted, Cambridge: Polity Press, 2005); David J. Kilcullen, 'Countering Global Insurgency', Journal of Strategic Studies 28(4), 2005, pp. 597-617; Rupert Smith, The Utility of Force: The Art of War in the Modern World (London: Penguin Books, 2006). Kaldor, ibid.; John Mueller, The Remnants of War (Ithaca, NY: Cornell University Press, 2004).

Didier Bigo, 'Internal and External Security(ies), the Möbius Ribbon', in Mathias Albert, Didier Bigo, Martin Heisler, Fritz Kratochwil, David Jacobson and Yosef Lapid (eds), Identities, Borders and Orders: Rethinking International Relations Theory (Minneapolis, MN: University of Minnesotta Press, 2001), pp. 91-136.

Peter Zirnite, Reluctant Recruits: The U.S. Military and the War on Drugs (Washington, DC: Washington Office on Latin America, 1997).

Laura L. Miller, 'Do Soldiers Hate Peacekeeeping? The Case of Preventive Diplomacy Operations in Macedonia', Armed Forces \& Society 23(3), 1997, pp. 415-449.

Robert B. Oakley, Michael Dziedzic and Eliot M. Goldberg (eds), Policing the New World Disorder: Peace Operations and Public Security (Washington, DC: National Defense University Press, 1998).

See, among others, Robert Perito, Where Is the Lone Ranger When We Need Him? America's Role for a Postconflict Stability Force (Washington, DC: US Institute of Peace Press, 2004); Robert Perito, 'Police in Peace and Stability Operations', International Peacekeeping 15(1), 2008, pp. 51-66; Thijs W. Brocades Zaalberg, Soldiers and Civil Power: Supporting or Substituting Civil Authorities in Modern Peace Operations (Amsterdam: Amsterdam University Press, 2006); David H. Bayley and Robert M. Perito, The Police in War: Fighting Insurgency, Terrorism, and Violent Crime (Boulder, CO: Lynne Rienner, 2010); Cornelius Friesendorf, The Military and Law Enforcement in Peace Operations: Lessons from Bosnia-Herzegovina and Kosovo (Vienna and Geneva: LIT/DCAF, 2010).

In a magnum opus, Thijs Zaalberg (ibid.) discusses the policing efforts of several countries. However, in his historical approach explanatory factors are hidden among a wealth of empirical material.

The terms maximum, intermediate and minimum force require explanation. In some cases their meaning is straightforward. Crowd and riot control units operating in larger groups and using non-lethal weapons represent an intermediate force option. In other cases different force levels are ambiguous; thus minimum force does not exclude lethal force. Indeed, aerial bombing can be considered as minimum force, to the extent that such bombing complies with principles of international law such as military necessity and discrimination between combatants and civilians. Ambiguity increases when the term 'use of force', as in this paper, encompasses deterrence/show of force. For example, when soldiers dismount from a tank and hold friendly talks with villagers without 
wearing full body armour and having their weapons at the ready, they display an ability to use maximum force while at the same time adopting a minimum force approach. This paper nevertheless employs the terms maximum, intermediate and minimum force, as these are commonly used by security practitioners and observers. The terms can be operationalised by looking at the material, educational, cultural, legal, organisational and operational characteristics of security forces. To draw on the examples above, police officers and the public would generally regard aerial bombing as maximum force. The soldiers in the village, in contrast, are versatile: their tank has significant firepower and offers protection, yet their communication skills and non-threatening posture are equally vital assets in a situation of high uncertainty.

T. Thomas Naylor, 'From Cold War to Crime War: The Search for a New "National Security" Threat', Transnational Organized Crime 1(4), 1995, pp. 37-56.

Tamara Makarenko, 'The Crime-Terror Continuum: Tracing the Interplay Between Transnational Organized Crime and Terrorism', Global Crime 6(1), 2004, pp. 129-145.

For empirical observations see Robert D. Kaplan, Imperial Grunts: On the Ground with the American Military, from Mongolia to the Philippines to Iraq and Beyond (New York: Vintage Books, 2005). Lutterbeck, note 11, pp. 45-68.

Kaldor, note 20.

Many would argue that this was the strategy of the British in Northern Ireland. See Martin van Creveld, The Changing Face of War: Combat from the Marne to Iraq (New York: Ballantine Books, 2008). For a more critical view see Rasmussen, note 10.

On this approach as practised by the US in Vietnam see John Nagl, Learning to Eat Soup with a Knife: Counterinsurgency Lessons from Malaya and Vietnam (Chicago, IL: University of Chicago Press, 2005), Part III. For an example of ruthless, indiscriminate elimination of opposition by domestic security forces see the discussion of Syria in van Creveld, ibid., pp. 235-246.

See James Cockayne and Adam Lupel (eds), Peace Operations and Organized Crime: Enemies or Allies? (London: Routledge, 2011). Martha K. Huggins, Political Policing: The United States and Latin America (Durham, NC: Duke University Press, 1998). See Paul F. Diehl, Peace Operations (Cambridge: Polity, 2008), Chapter 1. International Committee of the Red Cross, 'Customary IHL', available at www.icrc.org/customary-ihl/eng/docs/v1_rul_rule14. Also see Trevor Findlay, The Use of Force in UN Peace Operations (Oxford: Oxford University Press for SIPRI, 2002); Judith Gardam, Necessity, Proportionality and the Use of Force by States (Cambridge: Cambridge University Press, 2006).

United Nations, 'Code of Conduct for Law Enforcement Officials', adopted by General Assembly Resolution 34/169 of 17 December 1979, see in particular Article 3; Council of Europe, 'The European Code of Police Ethics', Recommendation Rec (2001)10, adopted by Committee of Ministers of the Council of Europe on 19 September 2001, and Explanatory Memorandum, March 2002, available at http://polis.osce.org/library/f/ 2687/500/CoE-FRA-RPT-2687-EN-European\%20Code\%20of\%20Police\%20Ethics.pdf; 
Senior Police Adviser to the OSCE Secretary General, International Police Standards: Guidebook on Democratic Policing (Geneva: DCAF, 2009), pp. 18-19.

On the difficulties of democracies in using force see David P. Auerswald, Disarmed Democracies: Domestic Institutions and the Use of Force (Ann Arbor, MI: University of Michigan Press, 2000); Stephen Watts, 'Air War and Restraint: The Role of Public Opinion and Democracy', in Matthew Evangelista, Harald Müller and Niklas Schörnig (eds), Democracy and Security: Preferences, Norms and Policy-making (London: Routledge, 2008), pp. 53-71. To be sure, democracy is not only a handicap when it comes to using force. In fact, democracies are more likely than non-democracies to win wars; see Dan Reiter and Allan C. Stam, Democracies at War (Princeton, NJ: Princeton University Press, 2002). I thank Anna Geis for her comments on this point.

United Nations, 'Guidelines for the Development of Rules of Engagement (RoE) for UN Peacekeeping Operations (Provisional)', UN Doc. MD/FHS/0220.0001, May 2002, UN Department for Peacekeeping Operations.

See, for example, United Nations, 'Report of the Secretary-General on the Implementation of the Report of the Panel on United Nations Peace Operations', 20 October 2000, available at www.un.org/peace/reports/peace_operations/docs/ 55_502e.pdf, paragraph $96 \mathrm{f}$.

Peter Viggo Jakobsen, 'The Emerging Consensus on Grey Area Peace Operations Doctrine: Will It Last and Enhance Operational Effectiveness?', International Peacekeeping 7(3), 2000, pp. 36-56. Martha Finnemore and Kathryn Sikkink, 'International Norm Dynamics and Political Change', International Organization 52(4), 1998, pp. 887-917. For a critique of the Kosovo intervention see Michael Pugh, 'Civil-Military Relations in the Kosovo Crisis: An Emerging Hegemony?', Security Dialogue 31(2), 2000, pp. 229-242. Ben F. Klappe, 'International Peace Operations', in Dieter Fleck (ed.), The Handbook of International Humanitarian Law (Oxford: Oxford University Press, 2009), pp. 635-673, at p. 654 For example, under IHRL the targeting of suspects is based on conduct, whereas under the law of armed conflict (IHL) it is based on status. Also, an IHRL approach limits the use of force, and the acceptable damage caused by the use of force, more than is the case with IHL. Similarly, for the police the threshold for the use of lethal force is generally higher than for the military. Van Creveld, note 34, pp. 231-234.

51 Noam Lubbell, Extraterritorial Use of Force against Non-State Actors (New York: Oxford University Press, 2010).

52 Nils Melzer, Targeted Killing in International Law (New York: Oxford University Press, 2009). Ben Saul, Defining Terrorism in International Law (New York: Oxford University Press, 2008).

54 Presentation by a legal adviser to the International Committee of the Red Cross, International Security Forum, Zurich, 31 May 2011. 
Carsten Stahn, "Jus ad Bellum", "Jus in Bello" ... "Jus post Bellum"? - Rethinking the Conception of the Law of Armed Force', European Journal of International Law 17(5), 2007, pp. 921-943; Brian Orend, 'Jus post Bellum: The Perspective of a Just-War Theorist', Leiden Journal of International Law 20(3), 2007, pp. 571-591. Eric Jaworski, "Military Necessity" and "Civilian Immunity": Where Is the Balance?', Chinese Journal of International Law 2(1), 2003, pp. 175-206. Zaalberg, note 26, pp. 315-320. In international deployment is it also the situational context which determines the applicable law. But this context does not determine the legal outlook. Up until 2009, for example, German soldiers in Afghanistan were held accountable on the basis of German criminal law, not IHL. Suerswald, note 19

Dale Stephens, 'The Lawful Use of Force by Peacekeeping Forces: The Tactical Imperative', International Peacekeeping 12(2), 2005, pp. 157-172. Douglas North, Institutions, Institutional Change and Economic Performance (Cambridge: Cambridge University Press, 1990). For a related definition see James G. March and Johan P. Olsen, 'The Institutional Dynamics of International Political Orders', International Organization 52(4), 1998, pp. 943-969, at p. 948.

See, for example, Peter J. Katzenstein (ed.), The Culture of National Security: Norms and Identity in World Politics (New York: Columbia University Press, 1996).

On the difficulty of change from a historical institutionalist perspective see Sven Steinmo, 'Historical Institutionalism', in Donatella Della Porta and Michael Keating (eds), Approaches and Methodologies in the Social Sciences: A Pluralist Perspective (Cambridge: Cambridge University Press, 2008), pp. 118-138.

These characteristics are partially drawn from Kraska, note 12; David M. Last, 'Blending Through International Deployment: Police and Military Roles in Peacekeeping and Stabilisation Operations', in Marleen Easton, Monica den Boer, Jelle Janssens, René Moelker and Tom Vander Beken (eds), Blurring Military and Police Roles (The Hague: Eleven International Publishing, 2010), pp. 33-55. The use of force is not the only difference between security forces - one could also examine procedures and purposes of intelligence collection. The police often use undercover agents and informants, methods such as forensics and wire-tapping, collect criminal intelligence that can be used in court and, being focused on casework, are likely to intervene at an early stage when observing criminal activities. The military and intelligence agencies, by contrast, are reluctant to interfere with crime when such interference stymies attempts to avert greater threats and apprehend the masterminds of enemy networks. Police-military conversion occurs when the military collects and makes available intelligence to contribute to the criminal prosecution of offenders, and the police collect and make available intelligence to contribute to the destruction of military enemies. Bayley, note 5, Part II. Charles Tilly (ed.), The Formation of National States in Western Europe (Princeton, NJ: Princeton University Press, 1975). 
Anthony Giddens, The Nation State and Violence (Berkeley, CA: University of California Press, 1985).

Beatrice Jauregui, 'Civilised Coercion, Militarised Law and Order: Security in Colonial South Asia and the Blue in Green Global Order', in Marleen Easton, Monica den Boer, Jelle Janssens, René Moelker and Tom Vander Beken (eds), Blurring Military and Police Roles (The Hague: Eleven International Publishing, 2010), pp. 57-77.

Admittedly, alliances complicate a distinction between inside and outside. For a NATO member during the Cold War, instability in another NATO member state affected internal security more than instability within the Warsaw Pact (see Kaldor, note 20, p. 28).

Wyn Rees and

Divergence or Convergence?', International Affairs 81(5), 2005, pp. 905-923.

There is a lack of data on differences in casualty aversion across countries, and a lack of scholarship on the causes of such differences. I thank Niklas Schörnig for his comments on this point.

Instead of ordering the intervening states alphabetically, this paper discusses them in the order of their weight in interventions, with the number of personnel deployed being the main indicator.

See Albrecht Schnabel, Ina Amann, Danail Hristov and Marc Krupanski, 'Mapping and Analysing Internal Roles of Armed Forces: A Research Report', paper presented at DCAF workshop, Geneva, 26 May 2011, pp. 99-109.

Geoffrey D. T. Shaw, 'Policemen Versus Soldiers, the Debate Leading to MAAG Objections and Washington Rejections of the Core of the British Counter-Insurgency Advice', Small Wars and Insurgencies 12(2), 2001, pp. 51-78.

On this reluctance see Zirnite, note 23 . On the military's role see Cornelius Friesendorf, US Foreign Policy and the War on Drugs: Displacing the Cocaine and Heroin Industry (London: Routledge, 2007).

In addition to supporting foreign police forces, the Pentagon has frequently trained US federal and local police forces in the use of force, among other fields. Schnabel et al., note 77, p. 22. Huggins, note 37.

See Dennis E. Keller, 'U.S. Military Forces and Police Assistance in Stability Operations: The Least-Worst Option to Fill the U.S. Capacity Gap', PKSOI Paper, Strategic Studies Institute, US Army War College, Carlisle, PA, August 2010. 
Nadelmann, note 9. For a vivid description of a famous US-led operation see Mark Bowden, Killing Pablo: The Hunt for the World's Greatest Outlaw (New York: Penguin Books, 2002).

The partial privatisation of US foreign policing reflects a general proclivity to outsource security functions to the private sector. It runs parallel, for instance, to a thriving private policing industry within the US.

US Army, The U.S. Army Marine Corps Counterinsurgency Field Manual (Chicago, IL: University of Chicago Press, 2007).

Jauregui, note 69, pp. 57-77.

Bruno C. Reis, 'The Myth of British Minimum Force in Counterinsurgency Campaigns During Decolonialisation (1945-1970)', Journal of Strategic Studies 34(2), 2011, pp. 245279; Huw Bennett, 'Minimum Force in British Counterinsurgency', Small Wars and Insurgencies 21(3), 2010, pp. 459-475.

See the examples in Barry Davies, Heroes of the SAS: True Stories of the British Army's Elite Special Forces Regiment (London: Virgin Books, 2007).

For an example see Richard Latham, Deadly Beat: Inside the Royal Ulster Constabulary (Edinburgh and London: Mainstream Publishing, 2001), p. 126.

Rasmussen, note 10.

Van Creveld, note 34, pp. 229-235.

Schnabel et al., note 77, pp. 95-96.

Indeed, one should not exaggerate the uniqueness of the British approach. After all, it was a British general and UNPROFOR commander, Michael Rose, who emphasised that UNPROFOR must not cross the 'Mogadishu Line'.

Jakobsen, note 44, p. 48.

Jerry H. Ratcliffe, 'Intelligence-Led Policing', in R. Wortley, L. Mazerolle and S. Rombouts (eds), Environmental Criminology and Crime Analysis (Cullompton: Willan, 2008).

For a discussion see Gunther Hellmann, 'Goodbye Bismarck? The Foreign Policy of Contemporary Germany', Mershon International Studies Review 40(1), 1996, pp. 1-39.

For examples from Afghanistan see Kersti Larsdotter, 'Exploring the Utility of Armed Force in Peace Operations: German and British Approaches in Northern Afghanistan', Small Wars and Insurgencies 19(3), 2008, pp. 352-373.

For insightful discussion see Thilo Marauhn, 'Streitkräfte zur Friedenssicherung im Ausland: zwischen militärischem und polizeilichem Einsatz', in Stephan Hobe, Eva-Maria Kieninger, Doris König, Thilo Marauhn, Kerstin Odendahl and Kirsten Schmalenbach (eds), Moderne Konfliktformen: Humanitäres Völkerrecht und privatrechtliche Folgen (Heidelberg: Berichte der Deutschen Gesellschaft für Völkerrecht, 2010), pp. 249-279.

Schnabel et al., note 77, p. 68.

Michael Head and Scott Mann, Domestic Deployment of the Armed Forces: Military Powers, Law and Human Rights (Basingstoke: Ashgate, 2009), p. 106.

Nick Squires, 'Troops Struggle to Stop Camorra Mafia Violence in Campania, Italy', Daily Telegraph, 8 October 2008, available at www.telegraph.co.uk/news/worldnews/ europe/italy/3159625/Troops-struggle-to-stop-Camorra-mafia-violence-in-CampaniaItaly.html. 
104 The Guardian, 4 August 2008, available at www.guardian.co.uk/world/2008/aug/ 04/italy.

105

See the overview of missions at www.carabinieri.it/Internet/Multilingua/EN/ MissionAbroad/03_EN.htm.

106

107

108

Jane M. O. Sharp, 'Dayton Report Card', International Security 22(3), 1997/1998, pp. 113-123; Slobodan Perdan, 'Security Sector Reform: The Building of Security in Bosnia and Herzegovina', Conflict, Security \& Development 6(2), 2006, p. 188.

109

Wesley K. Clark, Waging Modern War: Bosnia, Kosovo, and the Future of Combat (New York: Public Affairs, 2001), pp. 55-56. One of the lessons learned from UNPROFOR's 'dual key system', seen to have failed, was the establishment of NATO command after Dayton.

110 Richard K. Sele, 'Civil-Military Operations in the Post-War Sarajevo Region', Low Intensity Conflict and Law Enforcement 8(1), 1999, pp.87-118.

111

112

113 Zaalberg, note 26, p. 269.

114 For an example see ibid., p. 265.

115 Sharp, note 108, p. 134

116 Jeffrey Smith, 'U.S. Troops Capture Alleged War Criminal', Washington Post, 23 January 1998. It must be noted that US special forces provided vital intelligence for many arrest operations, even if US troops did not carry out the actual arrest themselves: Michael Smith, Killer Elite: Inside America's Most Secret Special Forces (London: Cassell, 2006), Chapter 8.

117 For a discussion see Michael A. Innes, 'Terrorist Sanctuaries and Bosnia-Herzegovina: Challenging Conventional Assumptions', Studies in Conflict \& Terrorism 28(4), 2005, pp. 295-305.

118

119 Project, US Army War College, Carlisle, PA, 19 March 2004, p. 11.

On human trafficking in peace operations see Keith Allred, 'Human Trafficking and Peacekeepers', in Cornelius Friesendorf (ed.), Strategies against Human Trafficking: The Role of the Security Sector (Vienna and Geneva: Austrian National Defence Academy/DCAF, 2010), pp. 299-328.

120 Interview with British military officer, Sarajevo, July 2008.

121 Richard J. Aldrich, 'From Ireland to Bosnia: Intelligence Support for UK Low Intensity Operations', in Ben de Jong, Robert Steele and Wies Platje (eds), Peacekeeping Intelligence: Emerging Concepts for the Future (Oakton, VA: OSS International Press, 2003), pp. 73-100.

122 Andrew et al., note 13, p. 437.

123 Tim Butcher, 'SAS Kills Serb War Crime Suspect and Grabs Another', Daily Telegraph, 11 July 1997. 
124

Zaalberg, note 26 , pp. 260-262.

Susan E. Penksa, Policing Bosnia and Herzegovina (2003-2005): Issues of Mandates and Management in ESDP Missions, CEPS Working Document no. 255 (Brussels: Centre for European Policy Studies, December 2006).

Cornelius Friesendorf and Susan E. Penksa, 'Militarized Law Enforcement in Peace Operations: EUFOR in Bosnia-Herzegovina', International Peacekeeping, 15(5), 2008, pp. 677-694; Antonio Prlenda, 'Vojskom na mafiju (army to combat mafia)', Oslobođenje, 24 November 2004.

David Leakey, 'ESDP and Civil-Military Cooperation: Bosnia and Herzegovina', in Anne Deighton and Victor Mauer (eds), Securing Europe? Implementing the European Security Strategy (Zurich: Centre for Security Studies, Swiss Federal Institute of Technology, 2006), pp. 63-64.

For examples of EUFOR's broad range of activities see the issues of EUFOR Forum, the mission's official journal, published in 2005.

Interview with British military officer, Sarajevo, July 2008.

Interview with German military officers, Sarajevo, July 2008.

Uli Rauss, 'Die Profis', Stern 46, 4 November 2004, p. 28.

See Susanne Koelbl, 'Gegen das Böse kämpfen', Der Spiegel, 24 September 2001, p. 42.

See the website of the Italian Defence Ministry at www.esercito.difesa.it/enUS/Activity/MissionsAbroad/Missionscarried/Pages/BosnialFORSFOR.aspx?status=Concl usa.

Interview, Sarajevo, October 2007.

Perito, note 26, p. 158.

Ibid., p. 171.

Zaalberg, note 26, p. 270; Perito, note 26, pp. 154, 161.

Perito, note 26, p. 176.

US Army Peacekeeping and Stability Operations Institute, 'SFOR Lessons Learned in Creating a Secure Environment with Respect for the Rule of Law', May 2000, available at www.au.af.mil/au/awc/awcgate/army-usawc/sfor_rule_of_law.doc, pp. 10-11.

Perito, note 26, p. 180.

For examples see Friesendorf, note 26, p. 53.

Perito, note 26, p. 177.

Interviews with Liaison and Observation Team officers, eastern Bosnia, winter $2007 / 2008$.

Interview with Italian Embassy official, Sarajevo, November 2007.

Interview with EUPM official, Sarajevo, November 2007.

Interview with EUFOR official, Sarajevo, November 2007.

Interview with SIPA official, June 2008.

Interview with EUFOR official, Sarajevo, July 2008.

Interviews with Carabinieri officers, Bosnia and Herzegovina, 2008.

On this pax mafiosa see Bundesnachrichtendienst, 'Lagebild zu OK-Aktivitäten', BND Analyse, 22 February 2005, available at http://mirror.wikileaks.info/wiki/bnd-kosovo- 
feb-2005.pdf, p. 4. On the continuation of this practice see Doreen Carvajal, 'In Balkans, Smuggling Forges a Rare Unity', New York Times, 24 October 2011.

151

Francesco Strazzari, 'L'Oeuvre au Noir: The Shadow Economy of Kosovo's Independence', International Peacekeeping 15(2), 2008, pp. 155-170; Institut für Europäische Politik, 'Operationalisierung von Security Sector Reform (SSR) auf dem Westlichen Balkan (Operationalising SSR in the Western Balkans)', report for German Bundeswehr, Berlin, 9 January 2007; Bundesnachrichtendienst, ibid.

Zaalberg, note 26, p. 315.

153 Cornelius Friesendorf, 'Problems of Crime-Fighting by "Internationals" in Kosovo', in James Cockayne and Adam Lupel (eds), Peace Operations and Organized Crime (London: Routledge, 2011), pp. 47-67; Institut für Europäische Politik, note 151. For journalistic criticism of international actors in Kosovo, see Maciej Zaremba, 'Series on Kosovo', Dagens Nyheter, 25 June 2007, available at www.dn.se/koloni-kosovo-av-maciejzaremba-1.703822. On the prosecution of suspected war criminals see Kosovo Compromise Staff, 'War Crimes Prosecutor Stunned by Relations Between Haradinaj and Chiefs of UNMIK', Kosovo Compromise, 11 December 2007, available at www.kosovocompromise.com/cms/item/topic/en.html?view=story\& $\mathrm{id}=353$ \& sectionld $=1$.

154 Colette Rausch, 'The Assumption of Authority in Kosovo and East Timor: Legal and Practical Implications', in Renata Dwan (ed.), Executive Policing: Enforcing the Law in Peace Operations (Oxford: Oxford University Press for SIPRI, 2002), p. 27.

Thomas S. Sowers, 'Beyond the Soldier and the State: Contemporary Operations and Variance in Principal-Agent Relationships', Armed Forces \& Society 31(3), 2005, p. 387; Zaalberg, note 26, p. 332.

156 International Crisis Group, 'The Policing Gap: Law and Order in the New Kosovo', ICG Balkans Report No. 74, Brussels, 6 August 1999, p. 3.

157 Zaalberg, note 26, Part IV.

158 On legal ambiguities see Roger F. M. Lorenz, 'The Rule of Law in Kosovo: Problems and Prospects', Criminal Law Forum 11(2), 2000, pp. 127-142; Colette Rausch (ed.), Combating Serious Crimes in Postconflict Societies: A Handbook for Policymakers and Practitioners (Washington, DC: US Institute of Peace Press, 2006), pp. 41, 51. Initially KFOR set up four multinational brigades and one multinational task force. These were replaced by multinational task forces in 2006 and multinational battle groups in 2010.

Thomas R. Mockaitis, Civil-Military Cooperation in Peace Operations: The Case of Kosovo (Carlisle, PA: Strategic Studies Institute, 2004), pp. 14-17.

161 On legal obligations by KFOR see John Cerone, 'Minding the Gap: Outlining KFOR Accountability in Post-Conflict Kosovo', European Journal of International Law 12(3), 2001, pp. 469-488.

162 Clive Baldwin, 'Implementation Through Cooperation? Human Rights Officers and the Military in Kosovo 1999-2002', International Peacekeeping 13(4), 2006, p. 497.

163 Council of Europe Committee on Legal Affairs and Human Rights, 'Alleged Secret Detentions in Council of Europe Member States', Information Memorandum II, 
Rapporteur Dick Marty, AS/Jur (2006) 03 rev., Council of Europe, Strasbourg (2006), p. 16; Spiegel Online, 'Everyone Knew What Was Going On in Bondsteel', 15 May 2005, available at www.spiegel.de/international/0,1518,388556,00.html. Gregory L. Naarden and Jeffrey B. Locke, 'Peacekeeping and Prosecutorial Policy: Lessons from Kosovo', American Journal of International Law 98(4), 2004, pp. 727-743.

Interview with Brigadier-General John. E. Davoren, commander, Multinational Task Force East, Camp Bondsteel, Kosovo, 8 January 2008.

Interviews with officials in Serbian enclave in southern Kosovo, January 2008.

In one case UNMIK asked a US KFOR Liaison and Monitoring (LMT) team to find information about crime, but the LMT did not know that crime existed in their area at all (interview with UNMIK Police officer, Belgrade, 4 October 2008). Interviews with journalist and Kosovo ministry official, Kosovo, October 2008. Institut für Europäische Politik, note 151, p. 80 (see also p. 117). Interview with former British legal adviser, Switzerland, May 2011.

Christian Jennings, 'SAS Troops Seize Kosovo Bomb Suspects', Daily Telegraph, 28 March 2001, available at www.telegraph.co.uk/news/1328191/SAS-troops-seize-Kosovo-bombsuspects.html.

Carlotta Gall, 'British Troops Replace French in Riot-Torn Kosovo Town', New York Times, 11 February 2000.

Zaalberg, note 26, pp. 332-333.

Interview with former British military officer, Geneva, 18 December 2008.

Interview with former British military officer, Geneva, 18 December 2008.

The other Quint nations were the US, France, Germany and Italy. The Quint is not the same as the Contact Group, which also included Russia.

Interview with EULEX official, Pristina, October 2008.

BBC News, 'German NATO Troops Face Serbs', 13 June 1999, available at http://news.bbc.co.uk/2/hi/europe/367997.stm.

Andreas Ulrich, 'Wir beginnen bei Null', Der Spiegel, 28 June 1999, available at www.spiegel.de/spiegel/print/d-13880820.html; Balkan-Blog, '1999-1', available at http://planken.org/balkans/chronology/kfor/1999-1.

Foreign Minister Joschka Fischer said that history not only told him that Germany should never wage war again but also that another Auschwitz should be prevented. See Nico Fried, 'Ich habe gelernt: Nie wieder Auschwitz', Süddeutsche Zeitung, 21 January 2005, available at www.sueddeutsche.de/politik/fischer-ich-habe-gelernt-nie-wiederauschwitz-1.915701.

181 Within the German sector, some contingents were more proactive than others. The Dutch were deeply traumatised by the Srebrenica experience and therefore keen to demonstrate that they would not tolerate inter-ethnic violence. As a consequence, Dutch troops improvised, trying, for example, to apprehend juvenile arsonists (see Zaalberg, note 26, Part IV).

Ulrich, note 179.

Frank Schuldt, 'Feldjäger im Kosovo', Y. Magazin der Bundeswehr 12/2001, available at www.militarypolice.de/modules.php?name=News\&file=article \&sid=12. 
Frankfurter Allgemeine Zeitung, 'Kosovo-Einsatz eine Katastrophe', 25 August 2004, available at www.faz.net/aktuell/politik/inland/kfor-truppe-kosovo-einsatz-einekatastrophe-1177693.html. Interviews with German military officers, MTF South, Prizren, 7 January 2008, and German military police officer, MTF South, Prizren, 31 October 2008.

Zaalberg, note 26, pp. 333-334, 382. This had detrimental consequences for minorities and also bore risks for two of Serbia's most important Serb Orthodox sites that happened to be located in the Italian sector, the monasteries of Peć and Dečani.

187 Zentrum für Internationale Friedenseinsätze, 'Organized Crime as an Obstacle to Successful Peacebuilding', report, Seventh International Berlin Workshop, 11-13 December 2003, pp. 42-44.

Christopher Holshek, 'The Operational Art of Civil-Military Operations: Promoting Unity of Effort', in Larry K. Wentz (ed.), Lessons from Kosovo: The KFOR Experience (Washington, DC: Department of Defense, Command and Control Research Program, 2002), p. 286. Interviews with Carabinieri officers, Kosovo, December 2007. Interview with Major-General Christian Millotat (ret.), Jugenheim, 2 February 2012.

191 Interview with KFOR officer, Pristina, December 2007.

192 Interviews with KFOR officers in Pristina and an MTF, Kosovo, January and November 2008.

193 Interviews with KPS officer, Pristina, October 2008, and Carabinieri officers, winter 2007/2008, Kosovo.

194 Interview with KFOR officer, Kosovo, November 2008.

195 Interview with Carabinieri officers, Kosovo, November 2008.

196 Interview with Carabinieri officer, Kosovo, November 2008; interview with Colonel Andrea Guglielmi, COM MSU, Pristina (MSU HQ), 12 December 2007.

197 Larry K. Wentz, 'Civil-Military Operations', in Larry K. Wentz (ed.), Lessons from Kosovo (Washington, DC: Department of Defense, Command and Control Research Program, 2002), p. 409. Ibid.

199 Perito, note 26, p. 188.

200 John C. Cockell, 'Civil-Military Responses to Security Challenges in Peace Operations: Ten Lessons from Kosovo', Global Governance 4(8), 2002, p. 496.

201 Interview with KFOR officer, Kosovo, November 2008.

202 Interview with MTF commander, November 2008.

203 James Dobbins, Michele A. Poole, Austin Long and Benjamin Runkle, After the War: Nation-Building from FDR to George W. Bush (Santa Monica, CA: RAND Corporation, 2008), p. xx. For an eyewitness account see Sarah Chayes, The Punishment of Virtue: Inside Afghanistan After the Taliban (New York: Penguin Books, 2006). Taliban', The Guardian, 25 July 2010, available at www.guardian.co.uk/world/2010/ jul/25/task-force-373-secret-afghanistan-taliban. In killing and detaining targeted 
individuals, OEF forces collaborated closely with Afghanistan's intelligence agency, the National Directorate for Security, which was considered effective and represented a (ruthless) state in a state.

ISAF, 'COMISAF's Initial Assessment, Commander NATO International Security Assistance Force, Afghanistan, and U.S. Forces', Kabul, 30 August 2009, available at http://media.washingtonpost.com/wp-srv/politics/documents/Assessment_Redacted_ 092109.pdf.

The focus was to be on insurgent leaders instead of paid foot soldiers. According to US General Stanley McChrystal, killing more local insurgents ran the risk of fuelling the insurgency: Briefing, ISAF HQ, 27 September 2009.

Gretchen Peters, Seeds of Terror: How Heroin Is Bankrolling the Taliban and Al Qaeda (New York: St Martin's Press, 2009), Chapter 7. NATO, 'NATO Steps Up Counter-narcotics Efforts in Afghanistan', available at www.nato.int/docu/update/2008/10-october/e1010b.html. Interview with former DEA agent, Kabul, 10 July 2011.

211 See Friesendorf, note 2, pp. 79-95.

212 Pratap Chatterjee, 'Policing Afghanistan: How Afghan Police Training Became a Train Wreck', TomDispatch, 21 March 2010, available at www.tomdispatch.com/post/ 175220/tomgram:_pratap_chatterjee,_failing_afghanistan's_cop House of Lords, The EU's Afghan Police Mission: Report with Evidence, European Union Committee, 8th Report of Session 2010-11 (London: The Stationery Office, 2011), p. 14. Interview with Major-General Stuart Beare, deputy commander NTM-A, Kabul, 6 October 2010; interview with EUPOL official, 10 October 2010. In June 2011, for example, an average of eight ANP officers were killed each day. See Joshua Partlow, 'Afghan Police Casualties Soar', Washington Post, 31 August 2011, available at www.washingtonpost.com/world/middle-east/afghan-police-casualtiessoar/2011/08/22/glQAHxN7qJ_story.html.

216 Julian Borger, 'US Reliance on Afghan Paramilitaries in Rural Areas Worries European Allies', The Guardian, 8 January 2012.

217 Briefing, ISAF HQ, 9 October 2010.

218 Quoted in International Crisis Group, 'Policing in Afghanistan: Still Searching for a Strategy', Asia Briefing No. 85, Brussels, 2008, pp. 9-10.

219 This piece of information was provided by Lieutenant-General Mirza Mohammad Yarmand, general director of the Criminal Investigation Department, Kabul, 11 July 2011. In addition to the DEA, by 2011 the FBI had a significant presence in Afghanistan. One of its main tasks was to partner with Afghan officials of the Major Crimes Task Force.

221 For examples see Doug Beattie, An Ordinary Soldier (London: Simon \& Schuster, 2008).

222 Larsdotter, note 99, p. 360.

223 Thomas Harding and Ben Farmer, 'Quarter of Senior Taliban Killed by SAS in "Kill or Capture" Targeting', Daily Telegraph, 1 September 2010, available at www.telegraph.co.uk/news/worldnews/asia/afghanistan/7973598/Quarter-of-seniorTaliban-killed-by-SAS-in-kill-or-capture-targeting.html. 
Judy Dempsey and John F. Burns, 'NATO Agrees to Take Aim at Afghan Drug Trade', New York Times, 10 October 2008, available at www.nytimes.com/2008/10/11/world/asia/ 11nato.html.

Chris Hughes, 'British Trained Afghan Special Forces Kill 50 Rebels in SAS-Style Assault', Daily Mirror, 25 July 2011, available at www.mirror.co.uk/news/top-stories/2011/07/25/ british-trained-afghan-special-forces-kill-50-rebels-in-sas-style-assault-11587523295113/. Interview with UN official, Kabul, 15 July 2011; see also the counternarcotics website of the Foreign \& Commonwealth Office, www.fco.gov.uk/en/global-issues/afghanistan/ counter-narcotics. Interviews with British diplomats, UK Embassy, Kabul, July 2009. Interview with EUPOL official, Kabul, 5 October 2010. Larsdotter, note 99, pp. 352-373.

For an example see Spiegel Online, 'Crucial Tip-Off: German Secret Service Helped Save Karzai in 2001', 5 September 2011, available at www.spiegel.de/international/world/ $0,1518,784385,00 . h t m l$. Rauss, note 131, p. 28. Welt Online, '70 Prozent zweifeln am Erfolg in Afghanistan', 5 October 2010, available at www.welt.de/politik/deutschland/article13642023/70-Prozent-zweifeln-am-Erfolg-inAfghanistan.html. Timo Noetzel, 'The German Politics of War: Kunduz and the War in Afghanistan', International Affairs 87(2), 2011, pp. 397-417. Interview, Camp Marmal, Mazar-e Sharif, 19 July 2011. Susanne Koelbl and Alexander Szandar, 'Not Licensed to Kill: German Special Forces in Afghanistan Let Taliban Commander Escape', Spiegel Online, 19 May 2008, available at www.spiegel.de/international/world/0,1518,554033,00.html. As early as 2008, at NATO's Budapest Summit, Germany had voiced objections. See Dempsey and Burns, note 224.

237 Interview with Bundeswehr colonel, southern Germany, spring 2010.

238 On the benefits of this approach see Friesendorf, note 2, pp. 79-95.

239 This paragraph is based on interviews with German police officers in Kabul and Mazar-e Sharif in October 2010 and July 2011, and officials of the Ministries of Interior and Defence in Berlin, autumn 2010.

240 It must be noted, though, that German special military forces supported SWAT-like police units of the ANP, the so-called provincial response companies, in northern Afghanistan. Interview with US general, Kabul, 23 July 2011; Johannes Korge, 'Der geheime Krieg der Elitesoldaten', Spiegel Online, 11 August 2011, available at www.spiegel.de/politik/ausland/0,1518,777002-4,00.html.

241 Phil Stewart, 'Italy, NATO Discuss Reducing Afghan Caveats', Thomson Reuters, 26 June 2008, available at www.reuters.com/article/2008/06/26/us-italy-nato-idUSL26717616 20080626.

242 BBC News, 'Italy Fury at "Taliban Pay" Claim', 15 October 2009, available at http://news.bbc.co.uk/2/hi/8309464.stm. 
243 Brookings Institution, 4 May 2009, available at www.brookings.edu/opinions/2009/ 0504_afghanistan_bindi.aspx. International Crisis Group, note 218, p. 5.

Personal observation, Central Training Center, Kabul, 14 July 2011.

Interview with Major-General Beare, Kabul, 6 October 2010.

Interview, Central Training Center, Kabul, 11 October 2010.

Interview with Brigadier-General Sebastiano Comitini, Combined Training Advisory Group - Police, NTM-A, Kabul, 13 July 2011.

Interview with EUPOL official, Kabul, September 2009.

Nagl, note 35, Part III.

Kaplan, note 31 - see for example p. 227.

Theo Farrell, 'World Culture and Military Power', Security Studies 14(2), 2005, pp. 448488.

On this view, as applied to foreign policy, see Amitai Etzioni, Security First: For a Muscular, Moral Foreign Policy (New Haven, CT: Yale University Press, 2007).

In parts of Africa citizens cooperate with police forces against criminals even though the police have a reputation for brutality and corruption; see Alice Hills, Policing PostConflict Cities (London: Zed Books, 2009). In violent provinces of Afghanistan people do not understand, and do not care about, the differences between the police and the military; they simply want security, and support anyone able to provide it (interviews with members of NGOs, Jalalabad, 16-17 July 2009).

On public acceptance of police corruption see Antonio Giustozzi and Mohammad Isaqzadeh, Afghanistan's Paramilitary Policing in Context: The Risks of Expediency (Kabul: Afghanistan Analysts Network, 2011), p. 16.

On public resistance to police reform see Hugo Frühling, 'The Impact of International Models of Policing in Latin America: The Case of Community Policing', Police Practice and Research 8(2), 2007, pp. 125-144.

Discussions with French military and gendarmerie officers, DCAF, Geneva, 26 May 2011. Keller, note 82, p. 37.

David H. Bayley, Democratizing the Police Abroad: What to Do and How to Do It (Washington, DC: US Department of Justice/National Institute of Justice, 2001), pp. 1315. See also David H. Bayley, 'Police Reform as Foreign Policy', Australian and New Zealand Journal of Criminology 38(2), 2005, p. 213.

'Police Reform', ibid., pp. 206-215.

For an analysis of intermediate force options see David Pion-Berlin, 'Neither Military nor Police: Facing Heterodox Security Challengers and Filling the Security Gap in Democratic Latin America', Democracy and Security 6(2), 2010, pp. 109-127.

See Hills, note 17, pp. 1-26.

For an example see Ronja Kempin and Christian Kreuder-Sonnen, 'Gendarmerieeinheiten in internationalen Stabilisierungsmissionen: Eine Option für Deutschland?', SWP-Studie 06, SWP, Berlin (2010), p. 6 (on p. 14, though, the authors concede the lack of empirical research). 


\title{
International Intervention and the Use of Force: Military and Police Roles
}

\author{
Cornelius Friesendorf
}

Intervening states apply different approaches to the use force in war-torn countries. Calibrating the use of force according to the situation on the ground requires a convergence of military and police roles: soldiers have to be able to scale down, and police officers to scale up their use of force. In practice, intervening states display widely differing abilities to demonstrate such versatility. This paper argues that these differences are shaped by how the domestic institutions of sending states mediate between demands for versatile force and their own intervention practices. It considers the use of force by Germany, Italy, the United Kingdom and the United States in three contexts of international intervention: Bosnia and Herzegovina, Kosovo and Afghanistan. The paper highlights quite different responses to security problems as varied as insurgency, terrorism, organised crime and riots. This analysis offers important lessons. Those planning and implementing international interventions should take into account differences in the use of force. At the same time, moving towards versatile force profoundly changes the characteristics of security forces and may increase their short-term risks. This difficulty points to a key message emerging from this paper: effective, sustainable support to states emerging from conflict will only be feasible if intervening states reform their own security policies and practices.

Cornelius Friesendorf is a lecturer at the Goethe-University Frankfurt and researcher at the Peace Research Institute Frankfurt. His work focuses on international intervention, security sector reform, policemilitary relations and strategies against armed non-state actors. He studied political science in Göttingen, Bristol, London, Berlin and Zurich, and has conducted fieldwork in South America, the Balkans, Central Asia and Afghanistan. From 2008 to 2009 he was a fellow at the Geneva Centre for the Democratic Control of Armed Forces within Special Programmes.

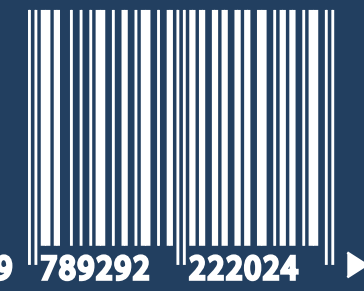

published by DCAF

(Geneva Centre for the Democratic Control of Armed Forces)

PO Box 1361

1211 Geneva 1

Switzerland 